\title{
Heterogeneity, trust and common-pool resource management
}

\author{
Fijnanda van Klingeren ${ }^{1}$ (D) $\cdot$ Nan Dirk de Graaf ${ }^{1}$
}

Accepted: 5 October 2020 / Published online: 26 November 2020

(C) The Author(s) 2020

\begin{abstract}
Increasing migration, leading to more heterogeneous societies, may challenge the successful management of common-pool resources (CPRs) directly due to the lack of shared interests, and indirectly by reducing trust amongst local commons users, speeding up depletion of vital natural and man-made resources. Since little research has been done on this topic, we analyse the relation between economic and sociocultural heterogeneity, trust and successful commons management for fisheries and irrigation systems. Using multiple imputations with chained equations, random forests and predictive mean matching, we adopt an innovative and technically advanced approach to employ Elinor Ostrom's famous CPR Database. Our approach enables us to include economic and sociocultural heterogeneity, trust and control variables in one model and to investigate both direct and indirect effects of heterogeneity on CPR success, which has not been attempted before. Results show no evidence of the negative relation between heterogeneity and CPR success. However, economic heterogeneity is negatively related to trust, and trust is found to be positively related to CPR success. Evidence is found for an indirect effect of economic heterogeneity through trust on CPR success.
\end{abstract}

Keywords Sustainable cooperation $\cdot$ Heterogeneity $\cdot$ Trust $\cdot$ Common-pool resources

\section{Introduction}

Societies are becoming more diverse on ethnic, cultural and economic dimensions due to growing migrant populations all over the world, especially in Northern Africa, Western Asia and sub-Saharan Africa (International Migration Report 2019 2019). This increasing heterogeneity may pose a challenge to the successful management of common-pool resources (CPRs) in two ways: (1) directly by diversifying interests amongst users and (2) indirectly by reducing trust amongst users. Both ways lead to decreased cooperation in CPRs. CPRs are natural or man-made resources-such as grasslands, communal forests, fishing grounds or irrigation systems - for which it is costly to exclude potential users (Ostrom 1990). Different from a public good, a common-pool resource may run out, making it vulnerable to the 'tragedy of the commons' as described by Hardin (1968), a situation where the shortterm dominant strategy of users is to use the limited resource

Fijnanda van Klingeren

fijnanda.vanklingeren@nuffield.ox.ac.uk

1 Nuffield College, University of Oxford, New Road, Oxford OX1 $1 \mathrm{NF}, \mathrm{UK}$ unlimitedly, which leads to its decay. The effect of increasing heterogeneity on the success of CPRs, and the role of trust in this process, is still contested (Baland and Platteau 1999; Bardhan and Dayton-Johnson 2002; Ruttan 2006, 2008; Varughese and Ostrom 2001). The aim of this paper is to gain insight into whether and how two types of heterogeneityeconomic and sociocultural-and their interplay with trust affect the success of a CPR, that is, its sustainable long-term use and quality of the resource.

Economic heterogeneity expresses inequalities in wealth, income and access to resources, and sociocultural heterogeneity represents disparities in language, ethnicity, religion and other cultural expressions (Baland and Platteau 1996; Bardhan and Dayton-Johnson 2002; Ruttan 2006). Most research argues that economic and sociocultural heterogeneity may result in increased costs of negotiation and bargaining due to a lack of shared ideas, values and incentives between individuals or groups of individuals (Aksoy 2019; Bardhan and DaytonJohnson 2002), that it may lead to unequal sharing of decision-making rights and different motivations to cooperate (Anderson and Paskeviciute 2006; Fung and $\mathrm{Au}$ 2014; Komakech et al. 2012) and that it may decrease social cohesion (Flache and Mäs 2008; Jehn et al. 1999). On the other hand, some research suggests positive effects of economic heterogeneity on the provision of collective goods, stating that 
it can lead to an inequality of incentives, which results in some appropriators being motivated enough to invest in collective action on their own-hereby carrying the costs of cooperation (Olson 1965).

In order to understand the indirect relation between heterogeneity and CPR success, we introduce trust as a mediator: there is evidence that trust is influenced by heterogeneity (Alesina and La Ferrara 2002; Delhey and Newton 2005; Ostrom 1990; Putnam 2007) and that it plays an important role in influencing societal outcomes (Fukuyama 1995; Putnam 2000; Uslaner 2002; Zak and Knack 2001). We will investigate the relation between trust and CPR success, and the role of trust in the indirect relation between heterogeneity and CPR success.

This paper will study 32 fisheries and 50 irrigation systems, using Elinor Ostrom's well-known Common-Pool Resource Database (Ostrom et al. 1989). ${ }^{1}$ Considering the field of study, which typically uses in-depth case studies, this is a relatively large database (Poteete and Ostrom 2004; Ruttan 2006). While the CPR Database was used before to investigate the relation between heterogeneity and CPR outcomes, this was done with correlations and Mann-Whitney $U$ tests on the available data, which contains a lot of missing observations (Ruttan 2006, 2008). Instead, the current paper uses innovative and advanced imputation techniques such as multiple imputations with chained equations, random forests and predictive mean matching to make the data suitable for including both economic and sociocultural heterogeneity, trust and control variables in the same model. This enables us to test the effects of one type of heterogeneity while controlling for the other, without decreasing the sample size due to the large amount of missing data, something that, to the extent of our knowledge, has not been attempted yet in previous research using this database. On top of that, our preparation of the data allows to test both direct effects of heterogeneity and trust on CPR success, and indirect effects of heterogeneity on CPR success through trust. This enables us to uncover part of the 'black box' of the theoretical mechanism.

We aim for theoretical progress in two ways. First, we test hypotheses regarding the relation between economic and sociocultural heterogeneity and CPR success for the combined sample, and two subsamples for fishing grounds and irrigation systems. ${ }^{2}$ Second, we formulate and test a hypothesis regarding the relation between trust and CPR success specifically for fisheries and irrigation systems. The outcomes are relevant not only for classic CPRs as fisheries and irrigation systems, but also for the rising number of contemporary institutions for collective action on food, infrastructure, health and energy,

\footnotetext{
${ }_{1}^{1}$ The database can be viewed and retrieved from https://seslibrary.asu.edu/cpr ${ }^{2}$ Ruttan $(2006,2008)$ takes two subsamples for irrigation systems and fisheries, but does not take economic and sociocultural heterogeneity, trust and/or control variables into account in one and the same model and does not test indirect effects.
}

such as citizen initiatives producing green energy and urban agriculture projects (Bravo and De Moor 2008; De Moor 2013a, b, 2018). In a time where mankind is rapidly depleting the earth's resources, research on success and failure of CPRs is more important than ever.

\section{The negative influence of heterogeneity}

Regarding economic heterogeneity it is suggested that large differences in wealth may result in a loss of incentives to cooperate for less wealthy appropriators if the benefits of cooperation are not high enough (Baland and Platteau 1999), if there is no wealthy appropriator willing to initiate collective action, or if the wealthy appropriators turn to their exit options-alternative ways to generate income - instead (Bardhan and Dayton-Johnson 2002; Jones 2004; Molinas 1998). Adding to this argument, Shanmugaratnam (1996) argues that sustainable use of CPRs is more challenging under a more unequal distribution of private wealth, as it leads to a diversification of interests amongst appropriators of the CPR. When actors have different interests, assurance mechanisms such as sanctioning are harder to implement since the actors are less likely to agree on them. However, these assurance mechanisms are needed for successful CPR management, making diversification of the interests of actors problematic. Heterogeneity in access to exit options can also have negative effects on the CPR itself: if resource appropriators have relatively rewarding earning opportunities outside of the appropriation of the resource, they may be more willing to comply with effort-restricting measures that are set in place to maintain the CPR. On the other hand, appropriators without access to exit options may not be willing to restrict their appropriation efforts as it will have a greater impact on their total income (Bardhan and Dayton-Johnson 2002; Gaspart and Platteau 2007). Evidence from observations and experiments supporting these arguments are manifold (Bardhan 2000; Hackett et al. 1994; Varughese and Ostrom 2001).

With respect to sociocultural heterogeneity, the general argument is that collective action is more likely to be established when the individuals involved have strong, multistranded, interpersonal relationships, share common interests, and have relatively stable group memberships (Anderson and Paskeviciute 2006; Ostrom 1990; Ostrom et al. 1992; Varughese and Ostrom 2001). Furthermore, Anderson and Paskeviciute (2006) consider heterogeneity to be an impediment to cooperation, as people feel threatened by others who are not part of their 'ingroup'.

If subgroups of appropriators within a CPR differ in ownership of assets, skills, knowledge or sociocultural 
characteristics, it is likely that these subgroups also differ in interests and preferred use of the resource. ${ }^{3}$ This can make it hard to reach agreements on the making and enforcing of rules due to a lack of mutual trust and the inability to understand each other. It can be reason for conflict and thus impedes collective action (Carpenter and Cardenas 2011; Gehrig et al. 2019; Johnson and Libecap 1982; Keuschnigg and Schikora 2014; Ostrom 1990; Varughese and Ostrom 2001). For instance, farmers may have different interests than nomads when it comes to the use of the resource, and men and women may have different actual and perceived costs and benefits, caused by a long history of gender inequality (Agarwal 1994, 1997; Molinas 1998; Varughese and Ostrom 2001).

Nettle and Dunbar (1997) focus on another aspect of sociocultural background, namely language; they state that speaking the same language facilitates a feeling of social allegiance, which is deemed important for the maintenance of group cohesion. Evidence in favour of these arguments is found by Wiessner (1977) with respect to language differences between tribes in Botswana. Another example of sociocultural homogeneity having a positive effect on sustainable cooperation is given by Singleton (2001) in an analysis of contemporary Pacific Northwest salmon fishing. The study describes how homogeneous Aboriginal tribes were very efficient and sustainable in the appropriation of salmon fishing grounds, in spite of the sometimes unequal economic results between individual members. The study describes how conflicts about appropriation only arose between Aboriginal tribes and the state. Based on a survey study of group membership in the USA, Alesina and La Ferrara (2000) concluded that residents from racially heterogeneous communities participate less in social activities. Carpenter and Cardenas (2011), employing a laboratory experiment with Colombians and Americans, discovered that mixed groups cooperate less than homogeneous groups. Keuschnigg and Schikora (2014) found in a study using public good games [PGGs] that religious heterogeneity decreases cooperation in the presence of a leader: whereas a generous contribution of leaders in homogeneous groups is met with reciprocity from the followers, this was not the case in heterogeneous groups. Vermillion (1999) mentions that the absence of social divisions is a requirement for collective action amongst farmers in devolution programs of irrigation systems, in which rights and responsibilities are transferred from the government to local water user groups. Lastly, Gaspart and Platteau (2007) concluded on basis of

\footnotetext{
3 Johnson and Libecap (1982) illustrate this in a case study concerning fishermen: fishermen with more skills and knowledge on how to set traps, trawling speed and the best locations for a good catch turn out to be the more successful fishermen. This heterogeneity in productivity will lead to different points of view regarding uniform fishing quotas and other restricting policies on resource subtraction, thus to higher transaction costs and a higher probability of conflict.
}

their case study of Senegalese fisheries that the division between native and migrant appropriators forms an insuperable problem for cooperation and mutual trust. Here, agreement on regulatory schemes has become nigh impossible.

Although the literature theoretically and empirically suggests predominantly a negative effect of heterogeneity, there are arguments for a positive effect, indirectly based on a well-known theory by Olson (1965), also known as the 'Olson effect':

In smaller groups marked by considerable degrees of inequality - that is, in groups of members of unequal "size" or extent of interest in the collective good - there is the greatest likelihood that a collective good will be provided; for the greater the interest in the collective good of any single member, the greater the likelihood that that member will get such a significant proportion of the total benefit from the collective good that he will gain from seeing that the good is provided, even if he has to pay all of the cost himself. (p. 34)

Although the link with economic heterogeneity cannot directly be distilled out of this quote, it is often interpreted as an argument in favour of a positive effect of economic heterogeneity on collective action: those with higher incomes will act as catalysts for collective action because they can afford it, and it is in their interest to do so (Baland and Platteau 1997, 1999; Bardhan and Dayton-Johnson 2002; Jones 2004; Ruttan 2006, 2008). In addition, it is likely that the Olson effect will only take place when inequality is large and there are actors that are indeed so rich that they can afford to pay to see collective action happen. It is unlikely that there are many of these cases in the current database. Based on the discussed literature, we therefore expect negative effects to be more probable. Hence, our first hypothesis reads: (hypothesis 1a) economic and (hypothesis $1 \mathrm{~b}$ ) sociocultural heterogeneity have a negative relation with CPR success.

\section{The role of trust}

A variable that we consider to play a role in the indirect effect of heterogeneity on CPR success is trust. The first part of the argument, illustrating the relation between heterogeneity and trust, is that people are more likely to trust someone who is more similar to themselves (Alesina and La Ferrara 2002; Coleman 1994), implying more mutual trust in a more homogeneous setting and less mutual trust in a heterogeneous one. People tend to trust members of their family and members of the same ingroup; be it racial, social, ethnic or based on something else (Alesina and La Ferrara 2002; Romano et al. 2017). Many studies point out a negative association between heterogeneity and trust. For instance, in their study using 
individual level data from the USA, Alesina and La Ferrara (2002) observe a negative relation between social distance and trust, and point out that being economically unsuccessful and living in a neighbourhood with a high degree of income inequality reduces trust. Delhey and Newton (2005) find that generalised trust is closely related to homogeneity in religious, cultural, social and political identification as well as to economic equality. Similarly, Gehrig et al. (2019) find in a lab-in-field CPR experiment in Zanzibar that less trusting fishermen overexploit the CPR more in heterogeneous groups, while they cooperate in the homogeneous group to achieve a sustainable use of the resource. Regarding causality, Leigh $(2006 \mathrm{a}, \mathrm{b})$ uses an instrumental variable approach in two studies, to show that increasing inequality and ethnic and linguistic fractionalisation reduce trust. Adding to that, Romano et al. (2017) find in a series of trust games in 17 countries that people are generally more trusting towards ingroup members than towards outgroup members.

The second part of the argument concerns the relation of trust with positive societal outcomes - in our case CPR success. Societies with high levels of trust amongst individuals yield a lesser need for the individuals to protect themselves from being taken advantage of by others in mutual transactions (Knack and Keefer 1997). Instead of formal institutions, mutual trust amongst individuals facilitates the use of informal agreements, leading to a decrease in transaction costs and a greater likelihood of economic efficiency and success (Alesina and La Ferrara 2002; Knack and Keefer 1997). Next to economic success, trust is known to promote cooperation and participation in social activities (Alesina and $\mathrm{La}$ Ferrara 2000; La Porta et al. 1997; Romano et al. 2017).

Empirical evidence supports this argument. A multitude of studies show a positive relation between high levels of interpersonal trust and economic growth of societies (Knack and Keefer 1997; La Porta et al. 1997; Zak and Knack 2001). Regarding the causal direction of the effects of trust, Acedo and Gomila (2013) find in an experiment involving an iterated prisoner's dilemma that higher trust results in higher levels of cooperation. Likewise, Gächter et al. (2004) find that more trusting people contribute more than less trusting people in three-person one-shot public good games.

Summarising, we hypothesise that (hypothesis 2a) economic and (hypothesis $2 b$ ) sociocultural heterogeneity have a negative relation with trust; (hypothesis 3 ) trust has a positive relation with CPR success; (hypothesis 4a) economic and (hypothesis $4 \mathrm{~b}$ ) sociocultural heterogeneity have a negative indirect relation with CPR success through trust.

\section{The relevance of sector type}

The cases analysed in this paper are either fisheries or irrigation systems. These two types of CPR vary in a multitude of aspects, which may influence the way sociocultural and economic heterogeneity and trust impact their success. First, whereas fishing grounds can be considered natural resources, irrigation systems are entirely man-made. This influences the way appropriators see the resource; an open-access resource available to everyone versus a self-made system only available to the ones who are granted access and/or are contributing to its maintenance (Gaspart and Platteau 2007). Second, whereas there are many different techniques to appropriate a fishing ground, which can be cause for conflict between appropriators (Gaspart and Platteau 2007), irrigation systems work one way for all users. Third, while mutual monitoring for irrigation systems is easy, this is more difficult for fishing grounds, where fishing boats cannot see each other during appropriation and where illegal appropriation forms a daily threat to the success of the CPR (Gaspart and Platteau 2007; Regmi 2007). ${ }^{4}$ Fourth, while the resource flow of a fishing ground can be considered relatively stable - conditional on the resource not being nearly depleted, the flow of water coming from the river that provides water to the irrigation system is less predictable (Regmi 2007). This poses a challenge for devising appropriation rules. For fishing grounds, many countries impose individual fishery quotas to improve sustainability of fishing activities (Sanchirico et al. 2006) or even moratoriums until specific fish populations regrow (see for instance Jiang et al. 2009; Khan et al. 2018; Palmer and Sinclair 2008). However, these rules do not necessarily make sense for an irrigation system, since the total discharge of a river is likely to change over time and is less dependent on use by farmers and more dependent on external factors such as the weather. Instead, time allocation rules are used that can vary depending on the availability of water (Regmi 2007). Fifth, whereas a fishing ground does not require much, if any, maintenance, irrigation systems do: man-made components such as check gates have to be checked regularly and fixed when broken. The government will take care of the maintenance if the system is government owned, but for systems that are not government owned, this requires farmers to work together (Vermillion 1999). This type of collective action is not required for fishermen, whose profits are not dependent on each other in this way. Lastly, a big difference between fishing grounds and irrigation systems is the constant disadvantage of appropriators in an irrigation system that are located downstream as opposed to at the head of the river (Ostrom 1990; Regmi 2007). The appropriators upstream are the first ones to receive water and are the least likely to be disadvantaged when other appropriators overexploit the resource. The appropriators downstream on the other hand, will experience

\footnotetext{
${ }^{4}$ This problem may be solved to an extent with modern technologies such as vessel monitoring systems (VMSs) and automatic identification systems (AISs), used to track fishing vessels. However, our data comes from before 1990, when neither VMS nor AIS were in use.
} 
the worst consequences of overexploitation of the resource by more upstream appropriators. Whereas fisheries usually have a rotation system of sorts to equalise appropriation time at better spots, this is not possible for irrigation systems (Ostrom 1990; Regmi 2007). A table describing differences in nature and various characteristics between fishing grounds and irrigation systems using variables from the CPR Database can be found in Appendix 1.

The differences between the two sector types may have implications for the expected effects of trust on CPR success: due to almost automatic mutual monitoring and the closedaccess and man-made nature of the resource, trust amongst appropriators may be less vital in order for the irrigation system to be successful. For fisheries however, trust amongst appropriators may play a more important role in reaching sustainable appropriation, as appropriators would need to trust each other not to overexploit the resource while not being able to see each other, or each other's actions, straight away. Based on the above we expect (hypothesis 5) that the relation of trust with CPR success is stronger for fishing grounds than for irrigation systems.

\section{Data and methods}

\section{Data}

We use the Common-Pool Resource Database compiled by Elinor Ostrom and her team (1989) to test our hypotheses. This database is based on a bibliography comprising over 1800 published and unpublished original CPR case studies from before 1990. A small subset of this bibliography was selected, ${ }^{5}$ and coded into the CPR Database using extensive survey forms containing over 600 questions on topics such as geographic and demographic features of the CPR location, boundaries and physical characteristics of the CPR, the situations faced and actions performed by appropriators of the CPR and the strategies of appropriators in subgroups (Ostrom 1990; Ostrom et al. 1989; Schlager 1990; Tang 1989). It was required that the material is written "by a researcher who has spent considerable time in the field" (Ostrom et al. 1989, p. 10) and that the material contains "key information about the structure of the resource, the rules used in organizing the resource, the strategies adopted by the appropriators, and the outcomes achieved" (Ostrom et al. 1989, p. 10). This way, 40 personyears of fieldwork, conducted by researchers interested in the field of CPRs, such as social scientists, historians and engineers, are captured in one database (Ostrom et al. 1989). The first

\footnotetext{
${ }^{5}$ Selection criteria are that the case study is the result of "extended fieldwork and that information be provided about (1) the structure of the resource system, (2) the attributes and behaviours of the appropriators, (3) the rules that the appropriators were using and (4) the outcomes resulting from the behaviours of the appropriators" (Ostrom 1990, p. xv).
}

major publication based on the CPR Database is Elinor Ostrom's Governing the Commons (1990), contributing to the Nobel Memorial Prize in Economic Sciences that she won together with Oliver E. Williamson, for her analysis of economic governance in CPRs. The dataset contains 32 fisheries and 50 irrigation systems for analysis of the variables of interest for this paper. The 3 CPRs that are neither fisheries nor irrigation systems are not included since they lack cases for making a comparison between sector types. The CPRs are located in 29 different countries from all over the world, although many are situated in the Middle East and Asia. A table comprising the cases and their sources used in this study can be found in Appendix 2.

\section{Measurements}

Many of the variables that are available in the database are recorded for both the beginning and the end of a period of time, during which "the actions of the appropriators are relatively consistent" (Ostrom et al. 1989, p. 352). These periods are of variable length, and different survey forms are provided for each period. These period forms, or 'time slices', are the observations in the dataset. Of the 82 separate CPRs that will be used for our analyses, seven have more than one period form filled out, so more than one time slice; this means that researchers conducting the case study found that during their study, several periods could be distinguished with specific information for each of them. Separate periods are considered as different observations since this period-specific information would get lost otherwise. Though the data has a multilevel structure-subgroups nested in time slices nested in CPR cases-we take all variables on the time slice level: operationalised variables are either original CPR level variables for a specific period or aggregated subgroup variables for that period. We do this because not all CPRs have multiple time slices or multiple forms coded for their separate subgroups: there are 123 forms for 82 CPRs, existing of 95 cases due to the extra period files. ${ }^{6}$ Cases that are twice in the dataset due to multiple coding forms for different subgroups are deleted, as we only use the aggregate information, which otherwise would be duplicate. The three cases that are neither fisheries nor irrigation systems are removed. In total the number of observations that can be used for analyses is $N=92$. If variables are recorded for both the beginning and the end of the period, the variables for the end of the period will be used

\footnotetext{
${ }^{6}$ The seven items used for sociocultural heterogeneity are, according to the codebook, only filled out if there are multiple subgroups present in the CPR (Ostrom et al. 1989). We thus assume that for each case there are multiple subgroups; since even for cases without an extra coding form, at least one of the seven items are still filled out. Even if there is one subgroup, filled out items about sociocultural heterogeneity provide information on the levels of heterogeneity in that CPR.
} 
(cf. Ruttan 2006, 2008). See the CPR Coding Manual for a more detailed description of the data (Ostrom et al. 1989).

\section{Dependent variables}

Unit quality: This variable is operationalised with an item indicating the 'quality of the units that are withdrawn from the resource'. There are five answering categories, ranging from 'extremely poor quality' $(0)$, to 'extremely high quality' (4). The quality of the appropriated units is an indicator of the quality of the resource in general, and thus represents a substantive part of the success of the CPR.

Balance: This variable is operationalised with an item indicating the "balance between the quantity of [resource] units withdrawn and the number of units available in the resource'. There are five answering categories, ranging from 'extreme shortage' (0) to 'quite abundant' (4). The balance between withdrawal and renewal of the resource indicates the health of the resource as well as the sustainability of the behaviour of the appropriators, and thus represents another substantive part of the success of the CPR.

\section{Independent variables}

Sector type: This independent variable indicates whether the CPR is an irrigation system (1) or not (0). Since the dataset exists only of irrigation systems and fishing grounds, the variable can be interpreted as being an irrigation system (1) versus a fishing ground ( 0 ). In the regression tables, this variable will be named 'Irrigation' for the main effects and will be abbreviated to 'Irr.' when used in an interaction effect.

Economic heterogeneity: The independent variable economic heterogeneity is operationalised as the highest level of variation in income within any subgroup within a CPR time slice (cf. Ruttan 2008). The item on variation in income has three outcome variables, ranging from 'low' (0) to 'moderate' (1) to 'high' (2).

Sociocultural heterogeneity: This independent variable consists of the maximum value found per time slice in any of seven items: the extent to which ethnic, racial, religious, caste, clan and gender identification and the language spoken affect communication between subgroups. ${ }^{7}$ All seven items have the same five-point response scale ranging from 'no difference along this variable' $(0)$ to 'large differences which significantly affect communication' (4).

Trust: This variable serves as both independent and dependent. It is an item indicating the extent of mutual trust amongst appropriators within the CPR on a three-point scale, with the categories 'low levels of trust' (0), 'modest levels of trust' (1) and 'moderate to high levels of trust' (2).

\footnotetext{
${ }^{7}$ We take this approach following Ruttan (2006) with the same rationale; we are interested in any kind of sociocultural heterogeneity that may take place, not in all of them at the same time.
}

\section{Control variables}

The following control variables were added to the final unit quality and balance models because they could influence success of the CPR: cultural view of the resource, number of users of the resource, closed access to the resource, opportunities for exit options, monetary, physical and social sanctions, pollution, level of financial pressure for immediate returns from the CPR, dependence on CPR for family income, the presence of consistently disadvantaged appropriators who are cut off from benefits and variation in availability of units over space. A more detailed description of the variables can be found in Appendix 3. Since most variables have no significant relations with the outcome variables, these models are not considered for the interpretation of the results but are presented in Appendix 3.

\section{Analytical strategy and causality}

To test the hypotheses, OLS regression will be used and the unstandardised coefficients will be interpreted. Even though the variables unit quality, balance, economic heterogeneity, sociocultural heterogeneity and trust are not continuous but ordinal, we will consider them continuous in the interest of simplicity of interpretation. This allows us to retain statistical powerespecially given the small sample size in the subsamples - by reducing degrees of freedom. In addition, it allows us to calculate indirect effects in a meaningful way. Following argumentation of amongst others Pasta (2009) and Williams (2018) on treating ordinal independent variables as continuous, a likelihood ratio test was completed to establish whether the models would significantly differ between treating the variables as ordinal or continuous (see Williams (2018) for a more extensive explanation of the test). The test concluded that economic heterogeneity, sociocultural heterogeneity and trust can be treated as continuous in the models. ${ }^{8}$ Ordinal logistic regression was also performed, with ordinal independent variables added as dummies. These models can be found in Appendix 4. The main results from the OLS analyses are largely supported by the more conservative ordinal logistic models. In addition, a robustness check was performed with an alternative operationalisation of economic and sociocultural heterogeneity, by taking the mean per time slice of the variation of income in CPR subgroups for economic heterogeneity and the mean of the seven sociocultural heterogeneity items instead of the maximum value. The results are very similar to the OLS models and can be found in Appendix 5. Relations found in the OLS models that

\footnotetext{
${ }^{8}$ A likelihood ratio tests between a constrained model treating the variables as continuous variables and an unconstrained model treating the variables as factors (Williams 2018) was performed for each iteration of the imputed dataset, and the $p$ values were plotted. For each test, the average $p$ value was higher than $a=0.05$; hence, we conclude that treating economic heterogeneity, sociocultural heterogeneity and trust as factor variables does not improve significantly on treating them as continuous variables.
} 
are not backed up by the ordinal logistic models or the robustness check models will not be considered robust.

Part of the analytical strategy is to analyse the entire sample, including both fisheries and irrigation systems, as well as two subsamples of fishery- and irrigation-only cases. This allows us to look at the general picture as well as to look at associations between variables that may be specific to the sector type. Questions that may arise after looking at the combined sample may be answered when looking at the separate samples. In addition, analysing the combined sample allows us to not miss out on the detection of associations between variables by retaining statistical power compared with the subsample analyses, given the small sample size. To test hypothesis 5 regarding the differences in the effect of trust on CPR success between fishing grounds and irrigation systems, an interaction between trust and sector type (Irr. $\times$ Trust) is added in addition to measuring the effect of trust in the two subsamples.

Although causal phrases are used throughout the discussion of the results, the observational data only allows to test associations, and causal conclusions can in principle not be drawn. However, we have some confidence in the assumed causal directions. Even though one could argue that trust could bring homogeneity about instead of homogeneity inducing trust, it is important to know that sociocultural heterogeneity (ethnic, racial, clan, caste, religious and gender identification and the language spoken) is rather fixed, as is economic inequality, although less so. Hence, in this respect, we have some confidence in the assumed causality (see also Leigh (2006a, b) and Romano et al. (2017)). With respect to trust and CPR success, it might also be possible that a high score on CPR unit quality and balance increases trust. However, experimental research of Acedo and Gomila (2013) and Gächter et al. (2004) discussed earlier provides evidence for the causal direction reflected in our hypotheses.

\section{Multiple imputation: mice, random forests and predictive mean matching}

All main independent variables have missing values - some more than others. The missingness of the independent variables is not correlated with relevant variables in the model. We assume the missing values to be missing at random (MAR) (Rubin 1987) and not dependent on unobserved data. ${ }^{9}$ This is, however, an untestable assumption. To prevent having to perform analyses on a smaller sample size than 92 cases due to

\footnotetext{
${ }^{9}$ The missingness of the variable economic heterogeneity is assumed to be a consequence of the way the data was constructed; the data is based on a survey that was filled out on the basis of information given by published case studies. Many case studies did not provide information on the variance of family incomes within CPRs, and the missingness is thus more likely related to coincidences or external factors rather than unobserved variables that could be of importance to the analyses and interpretation of results (see also Dong and Peng 2013).
}

missing observations in key variables, multiple imputation with chained random forests (RFs) (Breiman 2001; Van Buuren 2019) was performed, using the MissRanger package in $R$ (Mayer 2019), an adaptation of the MissForest package by Stekhoven and Bühlmann (2012) using the Ranger package (Wright et al. 2019). RF imputation accommodates nonlinearities and interactions and does not need a specific regression model to be defined. Predictive mean matching (PMM) was used to fill in the missing values with realistic imputations, that is, avoiding the imputation of continuous values in a discrete variable, for each iteration. PMM also enables imputed values to be endowed with realistic levels of local variability, effectively raising the variance of the resulting RFestimated conditional distributions to a more realistic level (Mayer 2019). We created 100 simulations and ensured the chained RFs would stop re-fitting after 30 iterations, though in every simulated imputed dataset, this procedure took at most 5 iterations, suggesting quick convergence to optimally imputed values. Imputation diagnostics, including the 'out of bag error' $(\mathrm{OOB})^{10}$ distribution per imputed variable, were inspected for key variables and supported our confidence in the imputation model. Research comparing MissForest imputation to other imputation techniques shows that MissForest performs well and in a lot of cases better than other established imputation techniques, even when applied to data with up to $30 \%$ missing values (Stekhoven and Bühlmann 2012). As the current database has 28\% missing data, using the MissRanger package based on the MissForest package is well suited. By making use of multiple imputation, both sociocultural and economic heterogeneity can be included in one model without reducing the sample size. The value of including both forms of heterogeneity in the model is that the risk of overestimating the influence of one by not controlling for the other is reduced. Table 1 provides insights in the original versus the imputed dataset.

The adjusted $R^{2}$ including the $95 \%$ confidence interval is provided for the models where possible. ${ }^{11}$ In addition, the fraction of missing information [FMI] is reported for the models where it was possible to calculate them, providing information on the uncertainty about the missing data, which affects the pooled standard errors (Pan and Wei 2016; Wagner 2010). These statistics are retrieved using the pool function of the Mice package (Van Buuren 2019). In addition, the Akaike information criterion [AIC] will be reported for every model. Lastly, tables stating the FMI per variable for main models will be provided in Appendix 6 .

\footnotetext{
$\overline{10}$ The out of bag error is the mean prediction error on each training sample; for a categorical variable, 'how often is a 'wrong' class imputed in a variable' and for continuous variables, it is $1-R^{2}$, that is, the unexplained variance (Stekhoven and Bühlmann 2012).

${ }^{11}$ For some of the subsample models, adjusted $R^{2}$ and FMI could not be calculated, as the Fisher transformation for pooled simulations could not be performed since some of the simulations had a negative $R^{2}$.
} 
Table 1 Imputed data statistics: key variables above line, control variables below line

Observations per simulation 1:100

\begin{tabular}{|c|c|c|c|c|c|c|c|}
\hline & \multirow[b]{2}{*}{ Complete } & & \multirow[b]{2}{*}{$\begin{array}{l}\text { OOB } \\
\text { Mean }\end{array}$} & \multirow[b]{2}{*}{ OOBSD. } \\
\hline & & Incomplete & Imputed & Total & Used $N^{*}$ & & \\
\hline Economic heterogeneity** & - & - & - & 123 & 92 & & \\
\hline Income variance & 65 & 58 & 58 & 123 & 92 & 0.13 & 0.02 \\
\hline Sociocultural heterogeneity** & - & - & - & 123 & 92 & & \\
\hline Ethnic identification & 101 & 22 & 22 & 123 & 92 & 0.00 & 0.01 \\
\hline Race identification & 101 & 22 & 22 & 123 & 92 & 0.02 & 0.00 \\
\hline Religious identification & 88 & 35 & 35 & 123 & 92 & 0.03 & 0.01 \\
\hline Gender identification & 101 & 22 & 22 & 123 & 92 & 0.04 & 0.01 \\
\hline Clan identification & 92 & 31 & 31 & 123 & 92 & 0.10 & 0.01 \\
\hline Caste identification & 71 & 52 & 52 & 123 & 92 & 0.06 & 0.01 \\
\hline Language spoken & 115 & 8 & 8 & 123 & 92 & 0.01 & 0.01 \\
\hline Unit quality & 118 & 5 & 5 & 123 & 92 & 0.05 & 0.01 \\
\hline Balance & 119 & 4 & 4 & 123 & 92 & 0.11 & 0.02 \\
\hline Trust & 112 & 11 & 11 & 123 & 92 & 0.06 & 0.01 \\
\hline Cultural view of resource & 102 & 21 & 21 & 123 & 92 & 0.08 & 0.01 \\
\hline Pollution & 91 & 32 & 32 & 123 & 92 & 0.01 & 0.00 \\
\hline Pressure & 37 & 86 & 86 & 123 & 92 & 0.05 & 0.01 \\
\hline Income dependence & 97 & 26 & 26 & 123 & 92 & 0.07 & 0.01 \\
\hline Variation over space & 105 & 18 & 18 & 123 & 92 & 0.02 & 0.01 \\
\hline Worst off & 74 & 49 & 49 & 123 & 92 & 0.01 & 0.00 \\
\hline Exit options & 80 & 43 & 43 & 123 & 92 & 0.12 & 0.01 \\
\hline Social sanctions (informal) & 72 & 51 & 51 & 123 & 92 & 0.17 & 0.02 \\
\hline Physical sanctions (informal) & 64 & 59 & 59 & 123 & 92 & 0.17 & 0.02 \\
\hline Formal sanctions & 62 & 61 & 61 & 123 & 92 & 0.22 & 0.02 \\
\hline Number of users & 102 & 21 & 21 & 123 & 92 & 0.37 & 0.03 \\
\hline
\end{tabular}

*Used $N$ is the total number of cases (123; all CPR types + duplicates due to multiple subgroup forms) minus duplicates (-28), minus other sector types $(-3)$, but keeping the different 'time slices' as mentioned before

**These variables were constructed after multiple imputation, before deleting duplicates

\section{Results}

In this section, Spearman's rank correlations will first be discussed to get an initial idea of the relation between variables. To test the hypotheses, we will discuss OLS regressions for the combined sample of both fishing grounds and irrigation systems, and the two subsamples separately. Both direct and indirect effects will be discussed. Lastly, the robustness of the found results is assessed by crosschecking the OLS regressions with the ordinal logistic regressions and the OLS regressions with the alternative operationalisation of the heterogeneity variables, both of which can be found in the appendices.

\section{Correlations}

Table 2 shows the relation between key variables using Spearman's rank correlation. The table shows the average coefficients over 100 imputed datasets and includes the standard errors in parentheses. The same table for the available case data is shown in Appendix 7, showing very similar results. It is shown that economic heterogeneity has a significant negative relation with trust in all three samples. In addition, it has a negative relation with balance in the combined and irrigation system sample. Sociocultural heterogeneity has a negative relation to trust in the combined sample and the irrigation sample, a significant negative relation to balance in the irrigation sample and a marginally significant negative relation with unit quality in the irrigation sample. Trust has a positive relation to both CPR success outcomes in all three samples except unit quality in irrigation systems. So far, the results thus partially support hypotheses $2 \mathrm{a}$ and $2 \mathrm{~b}$ and largely support hypothesis 3 . Only limited support is found for hypotheses $1 \mathrm{a}$ and $1 \mathrm{~b}$. Hypothesis 5 does not hold for balance but could yet hold for unit quality.

\section{Combined sample results}

The OLS regression models on CPR success using the imputed data are presented in Table 3. Model 1 and model 2 show that irrigation systems have significantly lower scores on unit quality $(B=-0.53, p<0.001)$ and balance $(B=-0.52, p=$ 0.005 ) than fishing grounds, indicating that there may be 
fundamental differences in success variables between the sector types. Model 3 and model 4 include the effect of sociocultural and economic heterogeneity and show that there is no significant relation between either sociocultural or economic heterogeneity and unit quality or balance, so far thus rejecting hypotheses $1 \mathrm{a}$ and $1 \mathrm{~b}$ stating a negative relation of heterogeneity with CPR success. Model 5 and model 6 include the effect of trust; model 5 shows a significant relation between trust and unit quality $(\mathrm{B}=0.20, p=0.040)$, and model 6 shows a significant relation between trust and balance $(B=0.54$, $p<0.001$ ), supporting hypothesis 3 stating that higher levels of trust are associated with CPR success. To test hypothesis 5 , models 7 and 8 include the interaction effect between trust and sector type. Model 8 shows no improvement in fit, but model 7 shows an increase from 0.28 to 0.39 for the adjusted $R^{2}$. The main effect of trust on unit quality, thus the relation between trust and unit quality in fishing grounds, is significant and positive $(B=0.53, p<0.001)$, adding to the support for hypothesis 3 . The interaction effect is significant and negative ( $B=-0.57, p<0.001)$ indicating that the relation between trust and unit quality for irrigation systems is basically zero and thus that trust amongst appropriators in a fishing ground may play a bigger role in achieving high levels of unit quality than in irrigation systems. ${ }^{12}$ This result only partially supports hypothesis 5; only in the case of unit quality. The main effect of trust on balance in model 8 , thus the relation between trust and balance for fishing grounds, is marginally significant and substantive $(B=0.43, p=0.053)$, indicating a 0.43 unit increase on a five-point scale of balance per increased unit of economic heterogeneity. Model 9 shows that economic heterogeneity $(B=-0.32, p=0.004)$ has a significant negative relation with trust, supporting hypothesis $2 \mathrm{a}$. No evidence for hypothesis $2 \mathrm{~b}$ is found. Lastly, model 10 shows that there is no significant main effect of sector type on trust, indicating that irrigation systems and fisheries do not necessarily differ in levels of trust, even though trust within each sector type may affect CPR success differently.

The indirect effects of economic heterogeneity on unit quality and balance through trust are calculated manually, using Sobel's (1982) product of coefficients approach for the coefficient, and Monte Carlo simulations for the standard error and two-sided $p$ value. ${ }^{13}$ Taking the coefficient of trust for fisheries from model 7 , we calculate a significant indirect

\footnotetext{
12 The main effect of trust for irrigations in model 7 is the main effect for trust ( $B=0.53)$ minus the interaction coefficient $(B=-0.59)$ which adds up to an effect of $B=-0.06$.

${ }^{13}$ Since the distribution of the product can be considered normal, as the product yields the same outcome as the difference between coefficients approach by Judd and Kenny (1981) (see also MacKinnon et al. (1995)), a Monte Carlo simulation was used, with 100,000 observations using two normal distributions based on the respective coefficients and standard errors of economic heterogeneity on trust and trust on unit quality or balance, after which a $z$ score, $t$ score and the two-sided $p$ value of the indirect effect could be calculated.
}

effect of economic heterogeneity on unit quality through trust $(B=-0.17, p=0.017) .{ }^{14}$ Using the trust coefficient for irrigation systems, we find a significant indirect effect of economic heterogeneity on balance through trust $(B=-0.20, p=0.033)$. These results partially support hypothesis 4 a stating the negative indirect effect of economic heterogeneity on CPR success through trust, but as no other significant indirect effects are found for the combined sample, the supportive evidence for hypothesis $4 \mathrm{a}$ is very limited and hypothesis $4 \mathrm{~b}$ is so far rejected. To check the robustness of the tests for the indirect effects, moderated mediation models using the mediate function in R were applied (Tingley et al. 2014), to test the difference in mediation effects of heterogeneity through trust on CPR success between fishing grounds and irrigation systems. ${ }^{15}$ The results support the found indirect effects and can be seen in Appendix 8.

\section{Separate sample results}

Table 4 shows the models testing the hypotheses separately for the fishing ground sample $(N=40)$ and the irrigation system sample $(N=52)$. In the fishing ground sample, a positive significant relation between trust and unit quality $(B=0.54$, $p=0.004$ ) in model 3 and a marginally significant relation between trust and balance $(B=0.50, p=0.062)$ in model 4 are found. Both results add to the support for hypothesis 3 . A marginally significant relation between economic heterogeneity and trust is visible $(B=-0.28, p=0.071)$ in model 5 . Although not significant at the $5 \%$ level, it is a substantive effect of a 0.28 point decrease in the three-point scale of trust per increased unit of economic heterogeneity, providing modest support for hypothesis $2 \mathrm{a}$.

With respect to the irrigation system sample, a hint of the indirect effect of economic heterogeneity by trust can be seen from models 2, 4 and 5. Model 2 shows a marginally significant negative relation of economic heterogeneity and balance $(B=-0.35, p=0.10)$, modestly supporting hypothesis $1 \mathrm{a}$. Model 4 shows a significant relation of trust and balance $(B=0.59, p=0.007)$, supporting hypothesis 3 . In addition, it shows the disappearance of the significance of economic heterogeneity. Lastly, model 5 shows a significant negative relation

\footnotetext{
14 The combined sample is used, but as the main effect of trust in models 7 and 8 is interpreted as the main effect of trust for fisheries, due to the addition of an interaction effect of sector type (irrigation system $=1$ ) and trust. The main effect of trust for irrigation systems is now the main effect of trust minus the interaction term coefficient. Hence, we can and must specify indirect effects of heterogeneity through trust for each sector type separately.

${ }^{15}$ Due to incompatibility of the moderated mediation analysis with the Mice paradigm and computational tools, we cannot obtain pooled standard errors for the estimates of the moderated mediation. As a result, we resolve to fit the moderated mediation to a representative dataset; this dataset is derived by taking the mean of numeric variables, and the mode of factor variables of the 100 imputed datasets, to create an average dataset.
} 


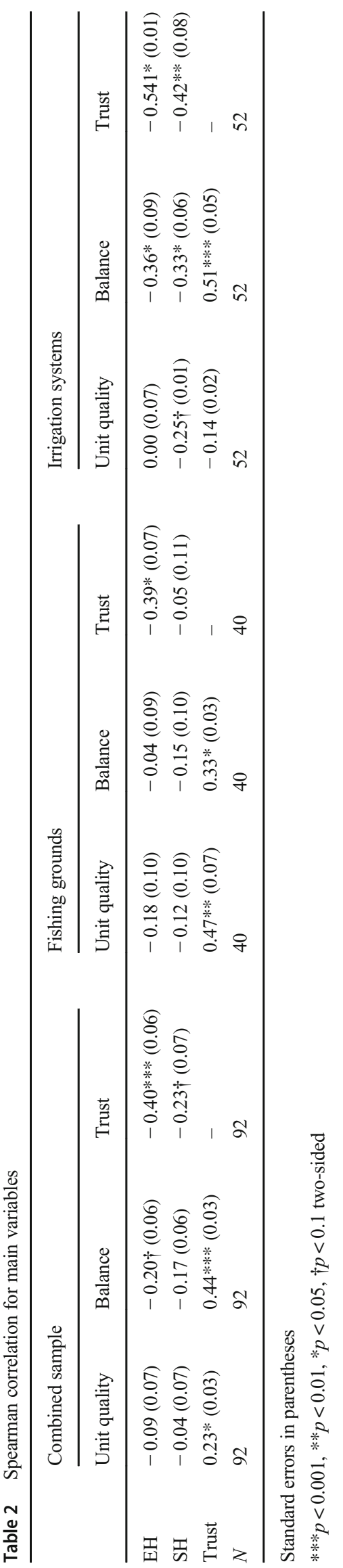

between economic heterogeneity and trust $(B=-0.29$, $p=0.050$ ), providing some support for hypothesis $2 \mathrm{a}$. Possibly, the results support hypothesis $4 \mathrm{a}$ for balance: the disappearance of the significant effect of economic heterogeneity from models 2 to 4 combined with the significant negative relation between economic heterogeneity on trust could be an indicator of an indirect effect of economic heterogeneity through trust on balance. Regarding sociocultural heterogeneity, model 1 shows a significant negative relation between sociocultural heterogeneity and unit quality $(B=-0.15, p=0.034)$ and model 5 shows a negative relation with trust $(B=-0.37, p=$ 0.026), providing partial support for respectively hypotheses $1 b$ and $2 b$ for irrigation systems. However, the significant effect of sociocultural heterogeneity on unit quality remains in model $3(B=-0.19, p=0.025)$ and trust is not significant, indicating that there is no indirect effect of sociocultural heterogeneity on unit quality through trust.

The indirect effects of economic or sociocultural heterogeneity on balance and unit quality for fishing grounds are not significant. For irrigation systems, the indirect effect of sociocultural heterogeneity on balance is marginally significant ( $B=-0.22, p=0.079)$, indicating modest support for the role of trust as stated in hypothesis $4 \mathrm{~b}$. The indirect effect of economic heterogeneity on balance through trust is just about not significant on the marginal level, but should, given the small sample size, not be ignored $(B=-0.17, p=0.109)$. To check the robustness of the tests for the indirect effects, moderated mediation models were applied. The models can be found in Appendix 8.

Table 5 shows an overview of the results found per hypothesis. Counting the three samples-combined, fishery and irrigation - and the three methods - OLS regression as shown in main tables, the ordinal logistic regression [OLR] and the robustness check [RC] models with the alternative operationalisation of economic and sociocultural heterogeneity - there are nine tests for each hypothesis, except for hypotheses $4 \mathrm{a}$ and $4 \mathrm{~b}$ which have not been calculated with the OLR models and thus have six tests. From this overview, we can conclude that there is convincing evidence for hypothesis $2 \mathrm{a}$ on the negative relation of economic heterogeneity with trust and hypothesis 3 on the positive relation of trust with CPR success, confirmed in, respectively, eight and nine tests out of nine. Hypothesis $1 \mathrm{~b}$ is only supported for balance in irrigation systems, and hypothesis 5 is only supported regarding unit quality; it is marked as supported in all tests because all tests point out that trust is more important for fishing grounds than irrigation systems for unit quality, but the hypothesis as a whole - encompassing both balance and unit quality-is still only partially supported. Hypothesis $4 \mathrm{a}$ is partially supported with three significant indirect effects out of six tests in addition to the supported hypotheses $2 \mathrm{a}$ and 3. 


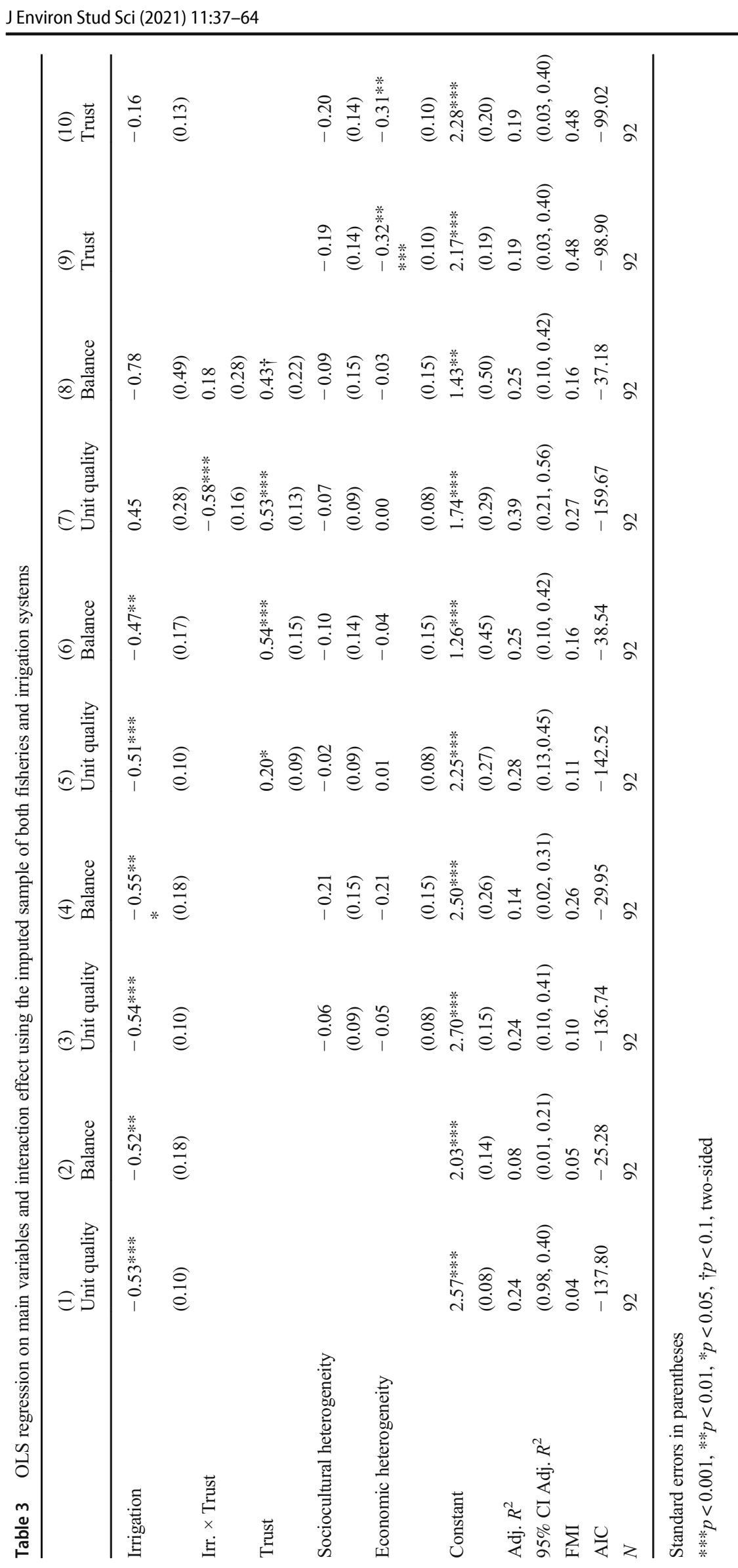

Springer 
Table 4 OLS regression on main variables using the imputed sample for fishing grounds (left) and irrigation systems (right)

Fishing grounds

Unit quality Balance

Trust

Sociocultural heterogeneity -0.01

(0.18)

Economic heterogeneity $\quad-0.14$

(0.16)

Constant

Adj. $R^{2}$

95\% CI Adj. $R^{2}$

AIC

$N$

Unit quality

$\begin{array}{ll}(4) & (5) \\ \text { Balance } & \text { Trust }\end{array}$

Irrigation systems

(1) (2)

(3)

Unit quality

Balance

\begin{tabular}{lllllllll} 
& $0.54 * *$ & $0.50 \dagger$ & & & & -0.10 & $0.59 * *$ & \\
& $(0.18)$ & $(0.26)$ & & & & $(0.07)$ & $(0.21)$ & \\
-0.14 & 0.01 & -0.12 & -0.05 & $-0.15^{*}$ & -0.23 & $-0.19 *$ & -0.01 & $-0.37 *$ \\
$(0.24)$ & $(0.16)$ & $(0.24)$ & $(0.17)$ & $(0.07)$ & $(0.20)$ & $(0.08)$ & $(0.20)$ & $(0.16)$ \\
-0.01 & 0.01 & 0.13 & $-0.28 \dagger$ & 0.03 & $-0.35 \dagger$ & 0.01 & -0.18 & $-0.29 *$ \\
$(0.23)$ & $(0.16)$ & $(0.24)$ & $(0.15)$ & $(0.07)$ & $(0.20)$ & $(0.07)$ & $(0.20)$ & $(0.14)$ \\
$2.26 * * *$ & $1.60^{* *}$ & $1.23 * *$ & $2.05^{* * *}$ & $2.18^{* * * *}$ & $2.09 * * *$ & $2.40^{* * *}$ & $0.73 * *$ & $2.29 * * *$ \\
$(0.43)$ & $(0.46)$ & $(0.70)$ & $(0.28)$ & $(0.08)$ & $(0.27)$ & $(0.20)$ & $(0.56)$ & $(0.20)$ \\
$-*$ & 0.22 & $-*$ & $-*$ & 0.09 & $-*$ & 0.12 & 0.29 & 0.30 \\
$-*$ & $(0.02,0.51)$ & $-*$ & $-*$ & $(0.00,0.31)$ & $-*$ & $(0.00,0.34)$ & $(0.09,0.53)$ & $(0.06,0.56)$ \\
-7.44 & -46.99 & -8.31 & -39.12 & -137.81 & -20.47 & -138.23 & -25.71 & -60.68 \\
40 & 40 & 40 & 40 & 52 & 52 & 52 & 52 & 52 \\
\hline$*$
\end{tabular}

Standard errors in parentheses

* Adjusted $R^{2}$ and FMI could not be calculated: the Fisher transformation for pooled simulations could not be performed since some of the simulations had a negative $R^{2}$.

$* * * p<0.001, * * p<0.01, * p<0.05, \dagger p<0.1$, two-sided

\section{Discussion}

The aim of this paper is to study whether and how economic and sociocultural heterogeneity affect the successful management of CPRs, to explore the role of trust and to see whether these relations differ for fisheries and irrigation systems. Using advanced imputation techniques to prepare the famous but challenging CPR Database allowed us to test the influence of two types of heterogeneity on CPR success at the same time, as well as looking at direct and indirect mechanisms. Existing literature predominantly suggests that both types of heterogeneity negatively influence collective action and therefore CPR success, that heterogeneity negatively affects mutual trust and that trust has a positive effect on societal outcomes.

For the multivariate analysis, we applied OLS regression models instead of ordinal logistic regression, favouring a simpler interpretation of coefficients. However, we tested all hypotheses in an ordinal logistic regression as well, plus we ran a model with alternative operationalisations of heterogeneity as a robustness check. In addition, we tested the found indirect effects through a moderated mediation analysis. Results are only considered robust if they are found for most of the combined and separate samples over the three analysis types. It appeared that neither form of heterogeneity has a robust significant relation with either measure of CPR success, contrary to a large body of existing literature. Economic heterogeneity, however, is found to be significantly negatively related to trust in all but one test, indicating that the role of economic heterogeneity regarding trust in CPRs is relevant. Trust has a positive association with both unit quality and balance in all tests, confirming the importance of mutual trust for

Table 5 Overview of results of hypothesis tests, where ' $x$ ' marks that support is found

\begin{tabular}{|c|c|c|c|c|c|c|c|c|c|}
\hline & \multicolumn{3}{|c|}{ Combined sample } & \multicolumn{3}{|c|}{ Fishing ground sample } & \multicolumn{3}{|c|}{ Irrigation sample } \\
\hline & OLS & OLR & $\mathrm{RC}$ & OLS & OLR & $\mathrm{RC}$ & OLS & OLR & $\mathrm{RC}$ \\
\hline 1a & & & & & & & $\mathrm{x}^{* *}$ & & $\mathrm{x}^{* *}$ \\
\hline $1 b$ & & & & & & & $x^{*}$ & $\mathrm{x}^{*}$ & $\mathrm{x}^{*}$ \\
\hline $2 \mathrm{a}$ & $\mathrm{x}$ & $\mathrm{x}$ & $\mathrm{x}$ & $\mathrm{x}$ & $\mathrm{x}$ & $\mathrm{x}$ & $\mathrm{x}$ & & $\mathrm{x}$ \\
\hline $2 b$ & & & & & & & $\mathrm{x}$ & & $\mathrm{x}$ \\
\hline 3 & $\mathrm{x}$ & $\mathrm{x}$ & $\mathrm{x}$ & $\mathrm{x}$ & $\mathrm{x}$ & $\mathrm{x}$ & $\mathrm{x}^{* *}$ & $\mathrm{x}$ & $\mathrm{x}^{* *}$ \\
\hline $4 a$ & $\mathrm{x}$ & - & $\mathrm{x}$ & & - & & & - & $\mathrm{x}^{* *}$ \\
\hline $4 b$ & & - & & & - & & $\mathrm{x}^{* *}$ & - & \\
\hline 5 & $\mathrm{x}^{*}$ & $x^{*}$ & $\mathrm{x}^{*}$ & $\mathrm{x}^{*}$ & $\mathrm{x}^{*}$ & $\mathrm{x}^{*}$ & $\mathrm{x}^{*}$ & $\mathrm{x}^{*}$ & $\mathrm{x}^{*}$ \\
\hline
\end{tabular}

Considering the small sample size and limited statistical power, a hypothesis is marked ' $x$ ' when supported with evidence on at least the marginal significance level of $\alpha=0.1$

* Only confirmed for unit quality

**Only confirmed for balance 
positive CPR outcomes. A distinction between sector type proves relevant, since the significant interaction of trust with sector type on unit quality implies that trust only has a positive effect on unit quality for fisheries, and not for irrigation systems, something we later confirm in the subsample analyses. Trust seems to play a role in upkeeping balance in irrigation systems, so the role of trust cannot be disregarded for irrigation systems. Regarding our calculations for the indirect effects, we find partial support: a significant indirect effect of economic heterogeneity on balance through trust is found in the combined sample. To invigorate the results, and to explore the findings that were not considered robust in the current analysis, more data should be gathered and more research conducted.

The difference between findings in the subsamples may be related to fundamental differences between sector types. For fishing grounds, both the quality (for instance, size of the fish) and the balance between renewal and subtraction may be affected by trust between appropriators. For irrigation systems on the other hand, the balance may be affected but the quality of the water in an irrigation system may be less threatened by a lack of trust. These findings illustrate the difficulty of drawing conclusions from results across sector types since a specific measure of CPR success might mean different things for different CPR types. It is especially because of these differences that it is theoretically interesting to compare different CPRs, as it helps to understand the mechanisms behind the failure or success of different types of resources.

The findings are relevant given the increasing number of contemporary CPRs, also known as citizen collectives, or institutions for collective action, such as local communities producing their own green energy and urban agriculture projects with community farms (De Moor 2013b). Like irrigation systems, green energy production and community farms are self-made systems, monitoring is relatively easy, production may be unstable due to the dependency on the weather, and maintenance is required-either by the government if government-owned, or through collective actions of farmers if not. If indeed our findings for irrigation systems apply to such CPRs, we can expect that trust amongst appropriators will benefit the balance rather than the quality of these CPRs, and maybe that trust may in general play a smaller role in achieving collective action, given that monitoring is easy which makes trust a less important factor. For CPRs where monitoring requires more effort, such as fisheries and communal forests, trust will be more important in achieving high quality of the resource units and a balanced resource.
It has to be noted that this study has some shortcomings and that there is potential for improvement and replication. First, although the database provides a relatively large sample for a field of research dominated by case studies, the sample size has limited statistical power. A substantial number of missing data for specific variables implied a suboptimal operationalisation of economic heterogeneity. The imputation method used is however innovative and provides imputation diagnostics, such as the OOB, that gives us confidence in the imputation process and its results. Next to this, we reported the FMI where possible, herewith disclosing the level of uncertainty we have about the imputation of missing data. Second, individual level data instead of our case study level data could have provided more information on the role of trust; there may be individual confounding factors influencing the level of mutual trust of appropriators, such as general level of trust in society, how long an appropriator has resided in the community, individual cultural views or the history of interactions between individual appropriators. In addition, the CPR Database only provides very broad categorisations, even for variables of great interest, like trust; more detailed measurements would provide more detailed results and subsequently more detailed conclusions. Third, the cases in the CPR Database are all from before 1989. Whereas the argument of difficult monitoring in fishing grounds may be true for most fisheries back then, there currently exist modern solutions: the vessel monitoring system (VMS), used from the late 1990s on, and the automatic identification system (AIS), implemented in the early 2000 's. Both systems have significantly improved monitoring of fishing activities worldwide (Longépé et al. 2018; Natale et al. 2015). AIS has the main purpose of avoiding collisions, but can also be used to track fishing activities (Kurekin et al. 2019; Longépé et al. 2018; Matsumoto et al. 2016; Natale et al. 2015; Wu et al. 2016). This may reduce the need for high levels of mutual trust amongst fishermen, as real-time monitoring is now a possibility. It is unlikely, however, that such systems are in use in the smallest CPRs in less developed areas. Depending on the availability of these modern technologies, the role of trust in achieving high unit quality and balance may thus not be discarded. Lastly, as we discussed, there may be reversed causality. As argued, we have reasons to believe that heterogeneity is indeed influencing trust and CPR success; we referred to studies using instrumental variables showing that heterogeneity negatively affects trust, and experimental studies showing that trust indeed positively affects societal outcomes such as cooperation. However, in future research the causality issues could be 
addressed by replicating our research on CPR success using for instance experimental methods, since laboratory experiments are tailor-made to point out causality.

The research question on cooperative behaviour in CPRs is not only fundamental to social sciences, but also to the current state of affairs concerning the use and depletion of natural and man-made resources, such as rainforests, fish populations, oil and gas. There is currently a rise of new CPRs: an increasing amount of green energy cooperatives, local community farms, collective gardens and care cooperatives are part of everyday life due to an increasing privatisation of social services (De Moor 2013a, 2013b, 2018). These commons too, may become subject to the risk of overexploitation. Next to that, 'classic' commons like fishing grounds, forests and pastures have new meanings nowadays, and are not only regarded as sources of products but also as conservation tools and leisure areas. Contemporary problems surrounding CPRs include amongst others landscape planning, water management and even climate change (Bravo and De Moor 2008). The investigation of the impact of societal characteristics such as heterogeneity and trust on cooperation could provide new insights into the use and preservation of these CPRs, demonstrating the contributions that social and environmental sciences can make to a sustainable society.

Acknowledgements We thank the Library on Governance in SocialEcological Systems for making the CPR Database publicly available and for providing detailed information about the database upon request. We also thank colleagues for their feedback and especially Prof. Tine de Moor.

Funding This research was supported by the Economic and Social Research Council.

Data availability The data is available at https://seslibrary.asu.edu/cpr

\section{Compliance with ethical standards}

Conflict of interest The authors declare that they have no conflict of interest

Code availability $\mathrm{R}$ code is available on the first author's GitHub.

\section{Appendix 1}

Table 6 Differences between fishing grounds and irrigation systems

\begin{tabular}{|c|c|c|}
\hline & $\begin{array}{l}\text { Fishing ground } \\
(N=40)\end{array}$ & $\begin{array}{l}\text { Irrigation system } \\
(N=52)\end{array}$ \\
\hline \multicolumn{3}{|c|}{ Variation of flow of resource units over space? } \\
\hline Yes & 40 & 32 \\
\hline No & 0 & 20 \\
\hline \multicolumn{3}{|c|}{ Variation of flow of resource units from year to year? } \\
\hline Yes & 38 & 37 \\
\hline No & 2 & 15 \\
\hline \multicolumn{3}{|c|}{ Variation of flow of resource units within a year? } \\
\hline Yes & 40 & 49 \\
\hline No & 0 & 3 \\
\hline \multicolumn{3}{|c|}{ Predictable variation of flow of resource units over space? } \\
\hline 1 (Highly predictable) & 0 & 0 \\
\hline 2 & 26 & 5 \\
\hline 3 & 7 & 44 \\
\hline 4 & 6 & 3 \\
\hline 5 (Highly unpredictable) & 1 & 0 \\
\hline \multicolumn{3}{|c|}{ Predictable variation of flow of resource units within a year? } \\
\hline 1 (Highly predictable) & 0 & 0 \\
\hline 2 & 29 & 6 \\
\hline 3 & 5 & 44 \\
\hline 4 & 2 & 2 \\
\hline 5 (Highly inpredictable) & 4 & 0 \\
\hline \multicolumn{3}{|c|}{ Predictable variation flow of resource units from year to year? } \\
\hline 1 (Highly predictable) & 0 & 0 \\
\hline 2 & 0 & 0 \\
\hline 3 & 0 & 1 \\
\hline 4 & 39 & 51 \\
\hline 5 (Highly unpredictable) & 1 & 0 \\
\hline \multicolumn{3}{|l|}{ Closed access $* *$} \\
\hline $\begin{array}{l}1 \text { (Yes, de jure and } \\
\text { effective) }\end{array}$ & 11 & 52 \\
\hline 2 & 1 & 0 \\
\hline 3 & 0 & 0 \\
\hline 4 & 12 & 0 \\
\hline 5 & 3 & 0 \\
\hline 6 & 3 & 0 \\
\hline 7 (No) & 10 & 0 \\
\hline \multicolumn{3}{|l|}{ Exit options $* *$} \\
\hline Less than $10 \%$ & 10 & 39 \\
\hline $10-25 \%$ & 1 & 1 \\
\hline $26-50 \%$ & 0 & 0 \\
\hline $51-75 \%$ & 1 & 2 \\
\hline $76-90 \%$ & 3 & 0 \\
\hline $91-100 \%$ & 25 & 10 \\
\hline
\end{tabular}

*See the CPR Coding Manual (Ostrom et al. 1989) for detailed description of variables

**See Appendix C for description of these variables 


\section{Appendix 2. Table of CPR cases in data}

Table 7 Generated with CPR Database, https://seslibrary.asu.edu/cpr

\begin{tabular}{|c|c|c|c|c|}
\hline Country & Resource name & Sector & Cases & Source(s) \\
\hline Australia & Lakes Entrance & Fishery & 2 & Sturgess et al. (1982) \\
\hline Australia & Port Phillip Bay & Fishery & 4 & Sturgess et al. (1982) \\
\hline Bangladesh & Nabagram Irrigation & Irrigation & 1 & Coward et al. (1979) \\
\hline Belize & Caye Caulker Lobsterfishing & Fishery & 1 & Sutherland (1986) \\
\hline Belize & San Pedro Spiny Lobster Fishery & Fishery & 1 & Gordon (1981) \\
\hline Brazil & Arembepe Fishery & Fishery & 1 & Kottak (1966) \\
\hline Brazil & Coqueiral Raft Fishery & Fishery & 1 & Forman(1970) \\
\hline Brazil & Valenca Fishery & Fishery & 3 & Cordell (1972) \\
\hline Canada & Baccalaos Cove Cod Fishery & Fishery & 1 & Powers (1984) \\
\hline Canada & Cat Harbour Cod Fishery & Fishery & 1 & Faris (1972) \\
\hline Canada & Chisasibi - James Bay Fishery & Fishery & 1 & Berkes $(1977,1982,1987)$ \\
\hline Canada & Fermeuse Cod Fishery & Fishery & 1 & Martin $(1973,1979)$ \\
\hline Canada & Petty Harbour Cod Fishery & Fishery & 1 & Shortall (1973) \\
\hline Canada & Port Lameron - Pagesville Finfishery & Fishery & 2 & Davis (1975), Davis (1984) \\
\hline Greece & Messolonghi-Etolico Lagoon Fishery & Fishery & 1 & Kotsonias (1984) \\
\hline India & A Tailend Watercourse in Area Two & Irrigation & 1 & Bottral (1981) \\
\hline India & Chawk 16,000 L Dhabi Minor Irrigation & Irrigation & 1 & $\begin{array}{l}\text { Reidinger }(1974,1980), \text { Gustafson and Reidinger (1971), Vander Velde } \\
\quad(1971,1980)\end{array}$ \\
\hline India & Jambudwip Fishery & Fishery & 1 & Raychaudhuri $(1968,1980)$ \\
\hline India & Kottapalle - Irrigation & Irrigation & 1 & Wade $(1985,1988)$ \\
\hline India & Sananeri Tank & Irrigation & 1 & Meinzen-Dick (1984) \\
\hline Indonesia & A Watercourse in Area Three & Irrigation & 1 & Bottrall (1981) \\
\hline Indonesia & Bondar Parhudagar Irrigation & Irrigation & 1 & Lando (1979) \\
\hline Indonesia & Saebah Communal System & Irrigation & 1 & Hafid and Hayami (1979) \\
\hline Indonesia & Silean Banua Irrigation & Irrigation & 1 & Lando (1979) \\
\hline Indonesia & Subak A & Irrigation & 1 & Geertz (1967) \\
\hline Indonesia & Takkapala Communal System & Irrigation & 1 & Hafid \& Hayami (1979) \\
\hline Iran & Deh Salm Irrigation & Irrigation & 1 & Spooner $(1971,1972,1974)$ \\
\hline Iran & Nayband Irrigation & Irrigation & 1 & Spooner $(1971,1972,1974)$ \\
\hline Iraq & El Mujarilin Irrigation & Irrigation & 1 & Fernea (1970) \\
\hline Jamaica & Farquhar Beach & Fishery & 1 & Davenport (1956) \\
\hline Japan & Ebibara Fishing Ground & Fishery & 1 & Brameld (1968) \\
\hline Korea & Kagoda anchovy grounds & Fishery & 1 & Han (1972) \\
\hline Laos & A watercourse in Nam Tan & Irrigation & 1 & Coward (1980) \\
\hline Malaysia & Kampong Mee Trawl Fishery & Fishery & 1 & Anderson and Anderson (1977) \\
\hline Malaysia & Perupok Fishery & Fishery & 1 & Firth (1966) \\
\hline Mexico & A Tramo in Diaz Ordaz & Irrigation & 1 & Downing (1974) \\
\hline Mexico & Andres Quinta Roo Lobster & Fishery & 1 & Miller (1982) \\
\hline
\end{tabular}


Table 7 (continued)

\begin{tabular}{|c|c|c|c|c|}
\hline Country & Resource name & Sector & Cases & Source(s) \\
\hline Mexico & Andres Quintana Roo Scalefish & Fishery & 1 & Miller (1982) \\
\hline Mexico & Ascension Bay Lobster Fishery & Fishery & 1 & Miller (1988) \\
\hline Nepal & Argali Raj Kulo Irrigation (Jethi Kulo) & Irrigation & 1 & Martin and Yoder (1983a, b, 1986) \\
\hline Nepal & Char Hazar Irrigation System (Charhajar) & Irrigation & 1 & Pradhan (1988), Laitos (1986) \\
\hline Nepal & $\begin{array}{l}\text { Chhahare Khola Ko Kulo, Baruwa Village } \\
\text { Panchayat }\end{array}$ & Irrigation & 1 & Water and Energy Commission Secretariat (1987) \\
\hline Nepal & Chherlung Thulo Kulo Irrigation & Irrigation & 1 & $\begin{array}{l}\text { Pradhan (1988), Martin and Yoder (1983a, b, 1986), Sharma et al. } \\
\text { (1989) }\end{array}$ \\
\hline Nepal & Lothar Irrigation System & Irrigation & 1 & Nirola and Pandey (1987), Pradhan (1988), Laitos (1986) \\
\hline Nepal & $\begin{array}{l}\text { Naya Dhara Ko Kulo (Kot Village } \\
\text { Panchayat) }\end{array}$ & Irrigation & 1 & Water and Energy Commission Secretariat (1987) \\
\hline Nicaragua & Miskito Turtle Fishery & Fishery & 1 & Nietschmann $(1972,1973)$ \\
\hline Pakistan & A Watercourse in Area One & Irrigation & 1 & Bottrall (1981) \\
\hline Pakistan & Main Watercourse in Gondalpur & Irrigation & 1 & Merrey and Wolf (1986) \\
\hline Pakistan & Watercourse Ten - Dakh Branch & Irrigation & 1 & Mirza and Merrey (1979) \\
\hline Pakistan & Watercourse in Punjab & Irrigation & 1 & Lowdermilk et al. (1975) \\
\hline Peru & Hanan Sayoc Irrigation & Irrigation & 1 & Mitchell $(1976,1977)$ \\
\hline Peru & Lurin Sayoc Irrigation & Irrigation & 2 & Mitchell $(1976,1977)$ \\
\hline Philippines & A Sitio in Zanjera Danum & Irrigation & 1 & Coward (1979) \\
\hline Philippines & Agcuyo Irrigation System & Irrigation & 1 & De Los Reyes (1980) \\
\hline Philippines & Cadchog Irrigation & Irrigation & 1 & De Los Reyes (1980) \\
\hline Philippines & Calaoaan Irrigation & Irrigation & 1 & De Los Reyes (1980) \\
\hline Philippines & Laoag-Vintar Irrigation & Irrigation & 1 & Ongkingco (1973) \\
\hline Philippines & Mauraro Irrigation & Irrigation & 1 & De Los Reyes (1980) \\
\hline Philippines & NIA Irrigation in San Antonio & Irrigation & 2 & De Los Reyes et al. (1980) \\
\hline Philippines & Nazareno-Gamutan Irrigation & Irrigation & 1 & Ongkingco (1973) \\
\hline Philippines & Oaig-Daya Irrigation System & Irrigation & 1 & De Los Reyes (1980) \\
\hline Philippines & Pinagbayanan Water Pumps & Irrigation & 1 & Cruz (1975) \\
\hline Philippines & Sabangan Bato Irrigation System & Irrigation & 1 & De Los Reyes (1980) \\
\hline Philippines & Silag-Butir Irrigation System & Irrigation & 1 & De Los Reyes et al. (1980) \\
\hline Philippines & Tanowong Bwasao Irrigation & Irrigation & 1 & Bacdayan (1980) \\
\hline Philippines & Tanowong Traditional Irrigation & Irrigation & 1 & Bacdayan (1980) \\
\hline Sri Lanka & Gahavalla Village & Fishery & 3 & Alexander (1982) \\
\hline Switzerland & Felderin Irrigation & Irrigation & 1 & Netting $(1974,1981)$ \\
\hline Taiwan & A Watercourse in Area Four & Irrigation & 1 & Bottrall (1981) \\
\hline Tanzania & Kheri Irrigation & Irrigation & 1 & Grey (1963) \\
\hline Thailand & A Chaek in Amphoe Choke Chai & Irrigation & 1 & Gillespie (1975) \\
\hline Thailand & A Chaek in Kaset Samakee & Irrigation & 1 & Gillespie (1975) \\
\hline Thailand & Chiangmai Irrigation & Irrigation & 1 & Potter (1976) \\
\hline Thailand & Muang Mai Irrigation & Irrigation & 1 & Tan-Kim-Yong (1983) \\
\hline Thailand & Na Pae Irrigation & Irrigation & 1 & Tan-Kim-Yong (1983) \\
\hline Thailand & Rusembilan Kembong Fishery & Fishery & 1 & Fraser $(1960,1966)$ \\
\hline Turkey & Alanya Fishery, Turkey & Fishery & 1 & Berkes (1986) \\
\hline Turkey & Ayvalik-Haylazli Coop Lagoon, Turkey & Fishery & 1 & Berkes (1986) \\
\hline Turkey & Tasucu Bay Fishery, Turkey & Fishery & 1 & Berkes (1986) \\
\hline USA & Lobsterfishing, Mount Desert Island, Maine & Fishery & 1 & Grossinger (1975) \\
\hline Venezuela & Chiguana & Fishery & 1 & Breton (1973) \\
\hline
\end{tabular}




\section{Appendix 3. Table including control variables}

A description of the control variables is provided following the table.

Table 8 OLS regression analyses on main dependent variables using the combined sample, including control variables

\begin{tabular}{|c|c|c|}
\hline & $\begin{array}{l}\text { (12) } \\
\text { Unit quality }\end{array}$ & $\begin{array}{l}\text { (13) } \\
\text { Balance }\end{array}$ \\
\hline Irrigation & $\begin{array}{c}0.50 \\
(0.40)\end{array}$ & $\begin{array}{l}-0.87 \\
(0.65)\end{array}$ \\
\hline Irr. $\times$ Trust & $\begin{array}{c}-0.60 * \\
(0.23)\end{array}$ & $\begin{array}{c}0.12 \\
(0.37)\end{array}$ \\
\hline Trust & $\begin{array}{l}0.48^{*} \\
(0.22)\end{array}$ & $\begin{array}{c}0.23 \\
(0.34)\end{array}$ \\
\hline Sociocultural heterogeneity & $\begin{array}{c}0.02 \\
(0.09)\end{array}$ & $\begin{array}{l}-0.01 \\
(0.17)\end{array}$ \\
\hline Economic heterogeneity & $\begin{array}{c}0.01 \\
(0.08)\end{array}$ & $\begin{array}{c}0.00 \\
(0.16)\end{array}$ \\
\hline Cultural view of the resource & $\begin{array}{l}-0.06 \\
(0.09)\end{array}$ & $\begin{array}{l}-0.14 \\
(0.15)\end{array}$ \\
\hline Number of users & $\begin{array}{c}0.00 \\
(0.00)\end{array}$ & $\begin{array}{c}0.00 \\
(0.00)\end{array}$ \\
\hline Closed access & $\begin{array}{l}-0.03 \\
(0.05)\end{array}$ & $\begin{array}{l}-0.08 \\
(0.08)\end{array}$ \\
\hline Exit options & $\begin{array}{c}0.01 \\
(0.04)\end{array}$ & $\begin{array}{c}0.03 \\
(0.06)\end{array}$ \\
\hline Monetary sanctions & $\begin{array}{c}0.00 \\
(0.06)\end{array}$ & $\begin{array}{l}-0.16 \\
(0.11)\end{array}$ \\
\hline Physical sanctions & $\begin{array}{l}-0.08 \\
(0.06)\end{array}$ & $\begin{array}{l}-0.12 \\
(0.10)\end{array}$ \\
\hline Social sanctions & $\begin{array}{c}0.07 \\
(0.07)\end{array}$ & $\begin{array}{c}0.14 \\
(0.13)\end{array}$ \\
\hline Pollution & $\begin{array}{c}-1.20 * \\
(0.51)\end{array}$ & $\begin{array}{l}-0.77 \\
(0.92)\end{array}$ \\
\hline Pressure & $\begin{array}{c}0.03 \\
(0.17)\end{array}$ & $\begin{array}{l}-0.05 \\
(0.30)\end{array}$ \\
\hline Income dependence & $\begin{array}{l}-0.09 \\
(0.13)\end{array}$ & $\begin{array}{c}0.27 \\
(0.21)\end{array}$ \\
\hline Worst off & $\begin{array}{l}-0.04 \\
(0.24)\end{array}$ & $\begin{array}{c}0.07 \\
(0.43)\end{array}$ \\
\hline Variation over space & $\begin{array}{l}-0.05 \\
(0.14)\end{array}$ & $\begin{array}{l}0.64 * \\
(0.29)\end{array}$ \\
\hline Constant & $\begin{array}{l}2.04 * * \\
(0.73)\end{array}$ & $\begin{array}{c}1.36 \\
(1.24)\end{array}$ \\
\hline $\begin{array}{l}\text { Adj. } R^{2} \\
95 \% \text { CI, adj. } R^{2}\end{array}$ & $\begin{array}{c}0.43 \\
(0.24,0.60)\end{array}$ & $\begin{array}{c}0.34 \\
(0.16,0.52)\end{array}$ \\
\hline FMI & 0.33 & 0.30 \\
\hline AIC & -156.00 & -34.86 \\
\hline$N$ & 92 & 92 \\
\hline
\end{tabular}

Standard errors in parentheses

$* * * p<0.001, * * p<0.01, * p<0.05, \dagger p<0.1$, two-sided 
Table 9 Description of control variables (as cited from the CPR Codebook (Ostrom et al. 1989))

\begin{tabular}{|c|c|}
\hline $\begin{array}{l}\text { Cultural view of the } \\
\text { resource }\end{array}$ & How does the general cultural view of the resource system and its use affect communication between subgroups? (scale 1-5) \\
\hline Number of users & What is the actual number of individuals in this group at the end of the period? (number) \\
\hline Closed access & $\begin{array}{l}\text { As of the end of this period, are the appropriators exercising or attempting to exercise closed access to this resource? Closed } \\
\text { access is exercised on a de facto base if it is NOT specifically sanctioned by some legitimate authority/ by a de jure base if it } \\
\text { IS sanctioned. Outsiders are persons who are not originally appropriators. (scale 1-7) }\end{array}$ \\
\hline Exit options & $\begin{array}{l}\text { What proportion of this subgroup works a substantial amount of time in activities not associated with appropriation from this } \\
\text { resource? (scale 1-6) }\end{array}$ \\
\hline Monetary sanctions & $\begin{array}{l}\text { If someone violated rules-in-use related to the appropriation process from this resource, how likely is it that an official monitor } \\
\text { or guard will move to impose sanctions? (scale } 1-5 \text { ) }\end{array}$ \\
\hline Physical sanctions & $\begin{array}{l}\text { If someone violates rules-in-use related to the appropriation process from this resource, how likely is he/she to encounter } \\
\text { physical sanctions imposed by other appropriators (who are not official monitors? (scale 1-5) }\end{array}$ \\
\hline Social sanctions & $\begin{array}{l}\text { If someone violates rules-in-use related to the appropriation process form this resource how likely is he/she to encounter social } \\
\text { sanctions imposed by other appropriators who are not monitors? (scale } 1-5 \text { ) }\end{array}$ \\
\hline Pollution & $\begin{array}{l}\text { Are there problems of pollution of this or other resources resulting from the way units are appropriated in end of period? (scale } \\
1-4)\end{array}$ \\
\hline Pressure & $\begin{array}{l}\text { Does the amount of capital required to set up an appropriation team, given the assets of members of this subgroup, place } \\
\text { pressure upon the appropriators to get immediate returns from appropriation }(\mathrm{Y} / \mathrm{N})\end{array}$ \\
\hline Income dependence & For most people in this subgroup, how dependent are they on this resource as a major source of family income? (scale 1-3) \\
\hline Worst off & Have the relatively worst off been cut out of their benefits from this resource or substantially harmed? $(\mathrm{Y} / \mathrm{N})$ \\
\hline Variation over space & Is there considerable variation over space in the availability of these units within the resource? $(\mathrm{Y} / \mathrm{N})$ \\
\hline
\end{tabular}

\section{Appendix 4 Ordinal logistic models}

For some models, the maximum likelihood estimates provide unreliably high standard errors due to the small sample size and the splitting of ordinal variables into multiple dummies in the model, as this increases the number of parameters to be estimated. We resolve to use a Bayesian approach for the models where the standard errors are too extreme, using the $\mathrm{R}$ function bayespolr from the arm package (Gelman and $\mathrm{Su}$ 2018). For instance, we are working on the logit scale, so a reasonable value for the standard deviation of a parameter over which we are very uncertain is around 2.5. ${ }^{16}$ The maximum likelihood approach for some of the models go up to over 200 points on the standard deviation, which is effectively meaningless, and an artefact of the small sample size. Hence, we resolve to regularise these standard deviation estimates by using a Bayesian prior encoding a reasonably large degree of uncertainty over the parameters. We stress however, that this prior is noninformative and only serves to control the standard deviation where needed.

For the subsamples, sociocultural heterogeneity was treated as continuous for two reasons. First, the combined sample model was modelled once with and once without treating sociocultural heterogeneity as continuous (the latter presented here in Appendix), which did not affect the coefficients of the other variables. Based on this we believe that treating sociocultural heterogeneity as either continuous or as ordinal does not impact the model significantly. Second, the subsamples are so small that adding the variable as separate dummies would decrease the already limited statistical power of the model, making it impossible to detect any possible relations between covariates.

${ }^{16}$ Which is the default scale parameter in the $\mathrm{R}$ function bayespolr. 


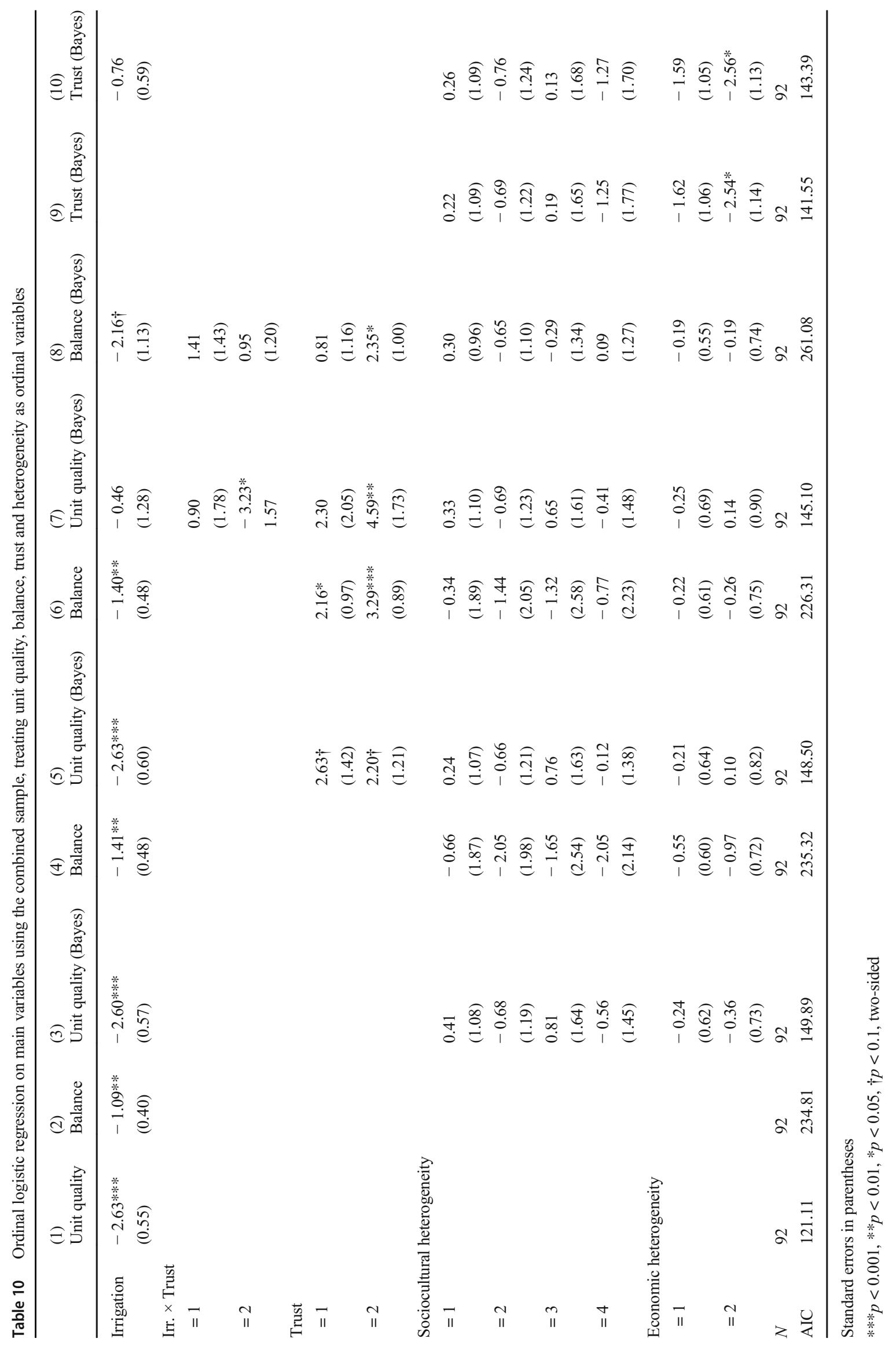




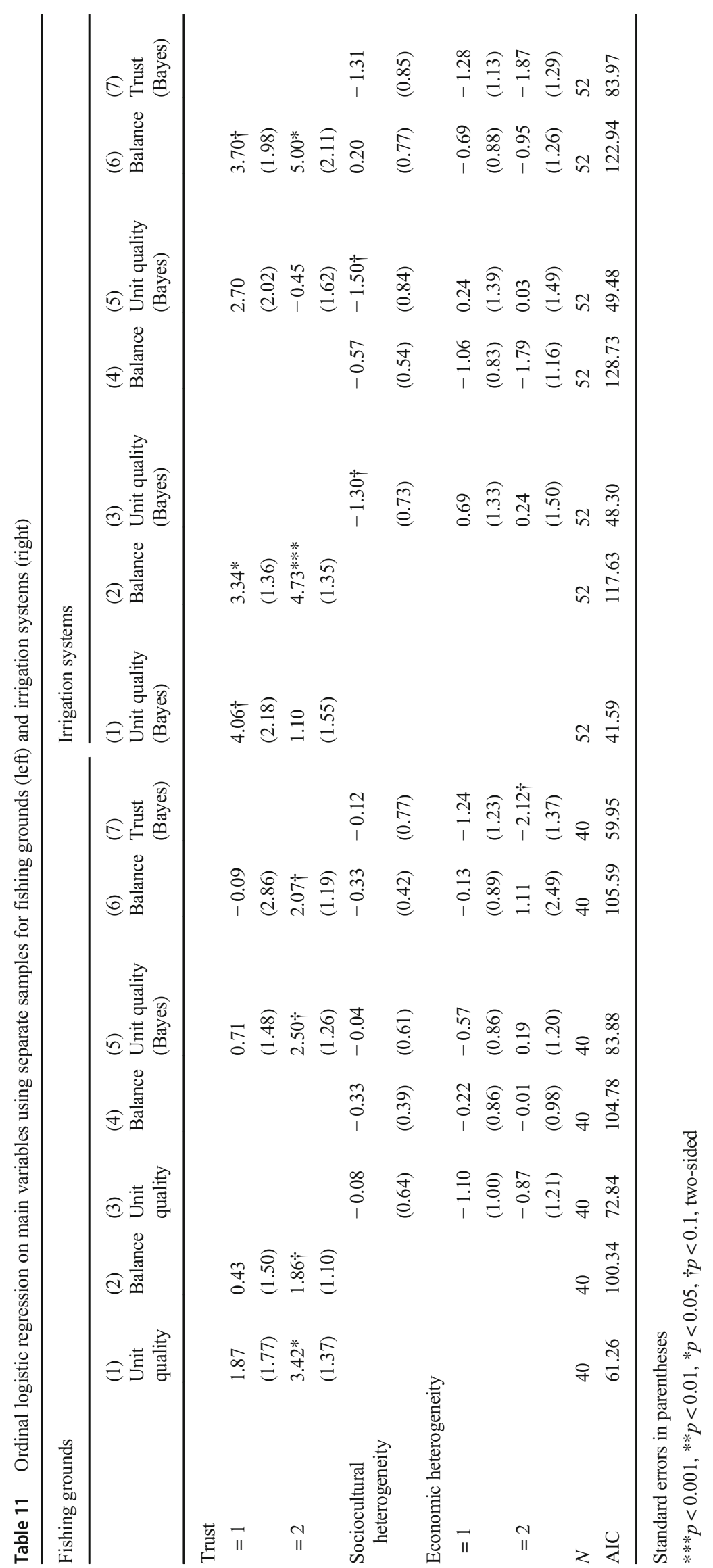




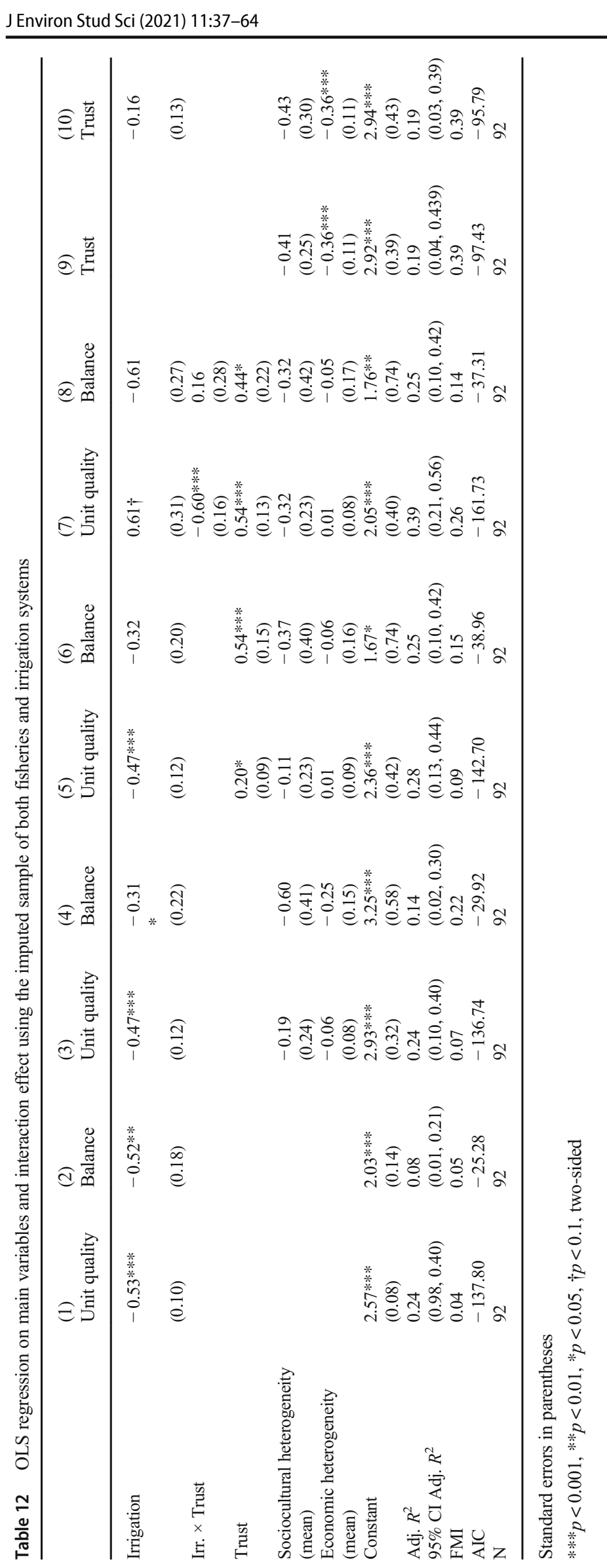

Springer 


\section{Appendix 5. Robustness checks}

for operationalisation of economic and sociocultural heterogeneity; mean

instead of max

Table 13 OLS regression on main variables using the imputed sample for fishing grounds (left) and irrigation systems (right)

\begin{tabular}{|c|c|c|c|c|c|c|c|c|c|c|}
\hline & \multicolumn{4}{|c|}{ Fishing grounds } & \multirow[b]{2}{*}{$\begin{array}{l}\text { (5) } \\
\text { Trust }\end{array}$} & \multicolumn{5}{|c|}{ Irrigation systems } \\
\hline & $\begin{array}{l}\text { (1) } \\
\text { Unit quality }\end{array}$ & $\begin{array}{l}(2) \\
\text { Balance }\end{array}$ & $\begin{array}{l}\text { (3) } \\
\text { Unit quality }\end{array}$ & $\begin{array}{l}\text { (4) } \\
\text { Balance }\end{array}$ & & $\begin{array}{l}\text { (1) } \\
\text { Unit quality }\end{array}$ & $\begin{array}{l}\text { (2) } \\
\text { Balance }\end{array}$ & $\begin{array}{l}\text { (3) } \\
\text { Unit quality }\end{array}$ & $\begin{array}{l}\text { (4) } \\
\text { Balance }\end{array}$ & $\begin{array}{l}\text { (5) } \\
\text { Trust }\end{array}$ \\
\hline \multirow[t]{2}{*}{ Trust } & & & $0.53 * *$ & $0.53 *$ & & & & -0.07 & $0.57 * *$ & \\
\hline & & & $(0.17)$ & $(0.25)$ & & & & $(0.07)$ & $(0.20)$ & \\
\hline \multirow{2}{*}{$\begin{array}{l}\text { Sociocultural } \\
\text { heterogeneity (mean) }\end{array}$} & 0.23 & -0.92 & 0.07 & -1.09 & -0.30 & $-0.41 * *$ & -0.34 & $-0.44 * *$ & -0.01 & $-0.59 \dagger$ \\
\hline & $(0.82)$ & $(1.18)$ & $(0.74)$ & $(1.15)$ & $(0.71)$ & $(0.14)$ & $(0.45)$ & $(0.15)$ & $(0.44)$ & $(0.35)$ \\
\hline \multirow{2}{*}{$\begin{array}{l}\text { Economic } \\
\text { heterogeneity (mean) }\end{array}$} & -0.16 & -0.06 & -0.01 & 0.10 & $-0.29 \dagger$ & 0.04 & $-0.43^{*}$ & 0.02 & -0.22 & $-0.37 *$ \\
\hline & $(0.19)$ & $(0.26)$ & $(0.18)$ & $(0.27)$ & $(0.16)$ & $(0.07)$ & $(0.20)$ & $(0.07)$ & $(0.21)$ & $(0.15)$ \\
\hline \multirow[t]{2}{*}{ Constant } & $2.71 * * *$ & $3.31 * * *$ & 1.58 & $2.32 * *$ & $1.88 * * *$ & $2.18 * * *$ & $2.85 * * *$ & $2.82 * * *$ & 1.01 & $3.23 * * *$ \\
\hline & $(0.30)$ & $(1.72)$ & $(1.13)$ & $(1.74)$ & $(1.03)$ & $(0.08)$ & $(0.69)$ & $(0.31)$ & $(0.94)$ & $(0.54)$ \\
\hline Adj. $R^{2}$ & $-*$ & - - & 0.22 & - * & - - & 0.12 & $-*$ & 0.12 & 0.30 & 0.25 \\
\hline $95 \%$ CI Adj. $R^{2}$ & - - & - - & $(0.02,0.51)$ & - * & - - & $(0.00,0.33)$ & $-*$ & $(0.00,0.33)$ & $(0.09,0.53)$ & $(0.06,0.56)$ \\
\hline AIC & -35.33 & -7.94 & -46.77 & -8.93 & -37.42 & -137.05 & -18.37 & -135.52 & -25.71 & -54.61 \\
\hline$N$ & 40 & 40 & 40 & 40 & 40 & 52 & 52 & 52 & 52 & 52 \\
\hline
\end{tabular}

Standard errors in parentheses

Adjusted $R^{2}$ and FMI could not be calculated: the Fisher transformation for pooled simulations could not be performed since some of the simulations had a negative $R^{2}$

$* * * p<0.001, * * p<0.01, * p<0.05, \dagger p<0.1$, two-sided

\section{Appendix 6. Fraction of missing information per variable for main tables}

Table 14 FMI per variable for OLS regression on main variables using the imputed sample

\begin{tabular}{|c|c|c|c|c|c|c|c|c|c|c|}
\hline & $\begin{array}{l}\text { (1) } \\
\text { Unit quality }\end{array}$ & $\begin{array}{l}(2) \\
\text { Balance }\end{array}$ & $\begin{array}{l}\text { (3) } \\
\text { Unit quality }\end{array}$ & $\begin{array}{l}(4) \\
\text { Balance }\end{array}$ & $\begin{array}{l}\text { (5) } \\
\text { Unit quality }\end{array}$ & $\begin{array}{l}(6) \\
\text { Balance }\end{array}$ & $\begin{array}{l}\text { (7) } \\
\text { Unit quality }\end{array}$ & $\begin{array}{l}(8) \\
\text { Balance }\end{array}$ & $\begin{array}{l}\text { (9) } \\
\text { Trust }\end{array}$ & $\begin{array}{l}(10) \\
\text { Trust }\end{array}$ \\
\hline Irrigation & 0.04 & 0.05 & 0.08 & 0.12 & 0.08 & 0.11 & 0.17 & 0.09 & & 0.17 \\
\hline Irr. $\times$ Trust & & & & & & & 0.20 & 0.12 & & \\
\hline Trust & & & & & 0.21 & 0.17 & 0.24 & 0.10 & & \\
\hline Sociocultural heterogeneity & & & 0.48 & 0.41 & 0.39 & 0.35 & 0.54 & 0.37 & 0.69 & 0.66 \\
\hline Economic heterogeneity & & & 0.29 & 0.38 & 0.32 & 0.40 & 0.33 & 0.40 & 0.38 & 0.38 \\
\hline$N$ & 92 & 92 & 92 & 92 & 92 & 92 & 92 & 92 & 92 & 92 \\
\hline AIC & -137.80 & -25.28 & -136.74 & -29.95 & -142.52 & -38.54 & -159.67 & -37.18 & -98.90 & -99.02 \\
\hline
\end{tabular}


Table 15 FMI per variable for OLS regression for imputed sample of fishing grounds
Fishing grounds

\begin{tabular}{lccccc}
\hline & $(1)$ & $(2)$ & $(3)$ & $(4)$ & $(5)$ \\
& Unit quality & Balance & Unit quality & Balance & Trust \\
\hline Trust & & & 0.20 & 0.17 & \\
Sociocultural heterogeneity & 0.35 & 0.30 & 0.31 & 0.32 & 0.43 \\
Economic heterogeneity & 0.32 & 0.33 & 0.37 & 0.36 & 0.32 \\
$N$ & 40 & 40 & 40 & 40 & 40 \\
AIC & -34.51 & -7.44 & -46.99 & -8.31 & -39.12 \\
\hline
\end{tabular}

Table 16 FMI per variable for OLS regression for imputed sample of irrigation systems

Irrigation systems

\begin{tabular}{ccccc}
$(1)$ & $(2)$ & $(3)$ & $(4)$ & $(5)$ \\
Unit quality & Balance & Unit quality & Balance & \multicolumn{1}{c}{ Trust } \\
& & 0.21 & 0.28 & \\
0.34 & 0.39 & 0.43 & 0.37 & 0.46 \\
0.38 & 0.46 & 0.36 & 0.48 & 0.40 \\
52 & 52 & 52 & 52 & 52 \\
-137.81 & -20.47 & -138.23 & -25.71 & -60.68
\end{tabular}

\section{Appendix 7. Spearman correlation of main variables with available (unimputed) data}

Table 17 Spearman correlation for main variables using available data

\begin{tabular}{|c|c|c|c|c|c|c|c|c|c|}
\hline & \multicolumn{3}{|c|}{ Combined sample } & \multicolumn{3}{|c|}{ Fishing grounds } & \multicolumn{3}{|c|}{ Irrigation systems } \\
\hline & Unit quality & Balance & Trust & Unit quality & Balance & Trust & Unit quality & Balance & Trust \\
\hline $\begin{array}{l}\text { Economic } \\
\text { heterogeneity }\end{array}$ & $-0.19(N=50)$ & $-0.25 \dagger(N=49)$ & $-0.56^{* * * *}(N=45)$ & $-0.17(N=21)$ & $0.09(\mathrm{~N}=21)$ & $-0.54 \dagger(N=20)$ & $-0.28(N=29)$ & $-0.51 * *(N=28)$ & $-0.59 * *(N=25)$ \\
\hline $\begin{array}{l}\text { Sociocultural } \\
\text { heterogeneity }\end{array}$ & $-0.19 \dagger(N=81)$ & $0.04(N=82)$ & $-0.17(N=77)$ & $-0.01(N=35)$ & $0.42 \dagger(N=36)$ & $0.06(\mathrm{~N}=35)$ & $-0.27 \dagger(N=46)$ & $-0.37 \dagger(\mathrm{N}=46)$ & $-0.46 * *(N=42)$ \\
\hline Trust & $0.21 \dagger(N=79)$ & $0.43 * * *(N=80)$ & - & $0.43 * *(\mathrm{~N}=36)$ & $0.30 \dagger(N=37)$ & - & $-0.15(N=43)$ & $0.53 * * *(\mathrm{~N}=43)$ & - \\
\hline
\end{tabular}

$* * * p<0.001, * * p<0.01, * p<0.05, \uparrow p<0.1$, two-sided 


\section{Appendix 8. Moderated mediation models}

Table 18 Moderated mediation models, testing the mediated effect of heterogeneity on CPR success through trust for fishing grounds and irrigation systems

\begin{tabular}{|c|c|c|c|c|c|c|c|c|}
\hline & \multicolumn{4}{|l|}{ Unit quality } & \multicolumn{4}{|l|}{ Balance } \\
\hline & \multicolumn{2}{|c|}{ Fishing ground } & \multicolumn{2}{|c|}{ Irrigation systems } & \multicolumn{2}{|c|}{ Fishing grounds } & \multicolumn{2}{|c|}{ Irrigation systems } \\
\hline & $\mathrm{EH}$ & $\mathrm{SH}$ & $\mathrm{EH}$ & SH & $\mathrm{EH}$ & $\mathrm{SH}$ & $\mathrm{EH}$ & $\mathrm{SH}$ \\
\hline ACME & $-0.233 * * *$ & $-0.185 * * *$ & 0.046 & 0.036 & $-0.193^{*}$ & $-0.155^{*}$ & $-0.283 * * *$ & $-0.230^{*}$ \\
\hline $\mathrm{ADE}$ & -0.028 & $-0.163 \dagger$ & -0.035 & $-0.167 \dagger$ & -0.069 & 0.057 & -0.076 & -0.065 \\
\hline Total effect & $-0.261 * * *$ & $-0.348 * * *$ & 0.012 & -0.130 & $-0.262 \dagger$ & 0.211 & $-0.359 * *$ & $-0.295 * *$ \\
\hline Prop. mediated & $0.898 * * *$ & $0.537 * * *$ & 0.350 & -0.207 & $0.716 \dagger$ & 0.596 & $0.792 * *$ & $0.745^{*}$ \\
\hline$N$ & 92 & 92 & 92 & 92 & 92 & 92 & 92 & 92 \\
\hline Simulations & 1000 & 1000 & 1000 & 1000 & 1000 & 1000 & 1000 & 1000 \\
\hline
\end{tabular}

$* * * p<0.001, * * p<0.01, * p<0.05, \dagger p<0.1$

Results are created using the mediate function in R (Tingley et al. 2014)

Due to incompatibility of the moderated mediation analysis with the Mice paradigm and computational tools, we cannot obtained pooled standard errors for the estimates of the moderated mediation. As a result, we resolve to fit the moderated mediation to a representative dataset; this dataset is derived by taking the mean of numeric variables, and the mode of factor variables of the 100 imputed datasets, to create an average dataset.

The above table supports the indirect effects as found using Sobel's (1982) product of coefficients approach for the coefficient, and Monte Carlo simulations for the standard error and two-sided $p$ value. In addition, the indirect effect of sociocultural heterogeneity through trust on unit quality for fishing grounds is found in the moderated mediation analysis, but this will not be regarded as a robust finding as we did not find this result using the more conservative data.

Open Access This article is licensed under a Creative Commons Attribution 4.0 International License, which permits use, sharing, adaptation, distribution and reproduction in any medium or format, as long as you give appropriate credit to the original author(s) and the source, provide a link to the Creative Commons licence, and indicate if changes were made. The images or other third party material in this article are included in the article's Creative Commons licence, unless indicated otherwise in a credit line to the material. If material is not included in the article's Creative Commons licence and your intended use is not permitted by statutory regulation or exceeds the permitted use, you will need to obtain permission directly from the copyright holder. To view a copy of this licence, visit http://creativecommons.org/licenses/by/4.0/.

\section{References}

Acedo C, Gomila A (2013) Trust and cooperation: a new experimental approach: trust and cooperation. Ann N Y Acad Sci 1299(1):77-83. https://doi.org/10.1111/nyas.12142

Agarwal B (1994) Gender and command over property: a critical gap in economic analysis and policy in South Asia. World Dev 22(10): 1455-1478. https://doi.org/10.1016/0305-750X(94)90031-0

Agarwal B (1997) Environmental action, gender equity and women's participation. Dev Chang 28(1):1-44. https://doi.org/10.1111/ $1467-7660.00033$

Aksoy O (2019) Crosscutting circles in a social dilemma: effects of social identity and inequality on cooperation. Soc Sci Res 82:148-163. https://doi.org/10.1016/j.ssresearch.2019.04.009

Alesina A, La Ferrara E (2000) Participation in heterogeneous communities. Q J Econ 115(3):847-904

Alesina A, La Ferrara E (2002) Who trusts others? J Public Econ 85(2): 207-234. https://doi.org/10.1016/S0047-2727(01)00084-6

Alexander P (1982) Sri Lankan fishermen: Rival capitalism and peasant society. Australian National University, Canberra

Anderson CJ, Paskeviciute A (2006) How ethnic and linguistic heterogeneity influence the prospects for civil society: a comparative study of citizenship behavior. J Polit 68(4):783-802. https://doi.org/10.1111/ j.1468-2508.2006.00470.x

Anderson EN Jr, Anderson MJ (1977) Fishing in troubled waters: Research on the Chinese fishing industry in West Malaysia. In: Lou TK (ed) Asian folklore and social life monographs, vol 100. The Chinese Association for Folklore, Taipei

Bacdayan AS (1980) Mountain irrigators in the Philippines. In: Coward EW Jr (ed) Irrigation and agricultural development in Asia: Perspectives from the social sciences. Cornell University Press, Ithaca, NY, pp 172-185 
Baland J-M, Platteau J-P (1996) Halting degradation of natural resources: is there a role for rural communities? Food and agriculture Organization of the United Nations, Rome

Baland J-M, Platteau J-P (1997) Wealth inequality and efficiency in the commons. Part I: the unregulated case on JSTOR. Oxf Econ Pap 49: $451-482$

Baland J-M, Platteau J-P (1999) The ambiguous impact of inequality on local resource management. World Dev 27(5):773-788. https://doi. org/10.1016/S0305-750X(99)00026-1

Bardhan P (2000) Irrigation and cooperation: an empirical analysis of 48 irrigation communities in South India. Econ Dev Cult Chang 48(4): 847-865. https://doi.org/10.1086/452480

Bardhan P, Dayton-Johnson J (2002) Unequal irrigators: heterogeneity and commons management in large-scale multi-variate research. In: Ostrom E, Dietz T, Dolsak N, Stern PC, Stonich S, Weber EU (eds) The Drama of the commons. National Academy Press, Washington, D. C, pp 87-112

Berkes F (1977) Fishery resource use in a subarctic Indian community. Hum Ecol 5(4):289-307

Berkes F (1982) Preliminary impacts of the James bay hydroelectric project, Quebec, on estuarine fish and fisheries. ARCTIC 35(4)

Berkes F (1986) Local-level management and the commons problem. Mar Policy 10(3):215-229

Berkes F (1987) Common property resource and Cree Indian fisheries in subarctic Canada. In: McCay BJ, Acheson JM (eds) The question of the commons: The culture and ecology of communal resources. University of Arizona Press, Tucson, pp 66-91

Bottrall AF (1981) Comparative study of the management and organization of irrigation projects. World Bank Working Paper No. 458, World Bank, Washington, DC

Brameld T (1968) Japan: Culture, education, and change in two communities. Holt, Rinehart and Winston, New York

Bravo G, De Moor T (2008) The commons in Europe: from past to future. Int J Commons 2(2):155-161 JSTOR

Breiman L (2001) Random forests. Mach Learn 45(1):5-32. https://doi. org/10.1023/A:1010933404324

Breton YD (1973) A comparative study of rural fishing communities in Eastern Venezuela: An anthropological explanation of economic specialization. Michigan State University, Ph.D. dissertation

Carpenter J, Cardenas JC (2011) An intercultural examination of cooperation in the commons. J Confl Resolut 55(4):632-651. https://doi. org $/ 10.1177 / 0022002710393922$

Coleman JS (1994) Foundations of social theory. Harvard University Press, Cambridge, MA

Cordell JC (1972) The developmental ecology of an estuarine canoe fishing system in northeast Brazil. Unpublished doctoral dissertation, Stanford University, Palo Alto, CA

Coward EW Jr (1979) Principles of Social Organization in an Indigenous Irrigation System. Hum Organ 38(1):28-36

Coward EW Jr (1980) Local organization and bureaucracy in a Lao irrigation project. In: Coward EW Jr (ed) Irrigation and agricultural development in Asia: Perspectives from the social sciences. Cornell University Press, Ithaca, NY, pp 329-344

Coward E, Walter Jr, Badaruddin A (1979) Village, technology, and bureaucracy: patterns of irrigation in Comilla District, Bangladesh. J Dev Econ 13:431-440

Cruz FA (1975) The Pinagbayan farmers' association and its operation. In: International Rice Research Institute (ed) Water management and operation. International Rice Research Institute, Los Banos, Philippines, pp 243-258

Davenport W (1956) A comparative study of two Jamaican fishing villages. Unpublished doctoral dissertation, Yale University, Stanford, CT

Davis A (1984) Property rights and access management in the small boat fishery: A case study from southwest Nova Scotia. In: Lamson C, Hanson AJ (eds) Atlantic fisheries and coastal communities: fisheries decision-making case studies. Dalhousie Ocean Studies Programme, Halifax, pp 133-164

Davis AFA (1975) The organization of production and market relations in a Nova Scotian inshore fishing community. University of Manitoba Anthropology Papers No. 16, University of Manitoba Department of Anthropology, Winnipeg

De los Reyes RP (1980) 47 communal gravity systems: Organization profiles. Quezon City, Philippines. Institute of Philippine Culture, Ateneo de Manila University

De los Reyes RP, Borlavian S, Gatdula G, Viado MF (1980) Communal gravity systems: Four case studies. Quezon City, Philippines: Ateneo de Manila University. In: Institute of Philippine Culture

De Moor T (2013a) De herontdekking van het Collectief. Samenleving En Politiek 20(4):29-38

De Moor T (2013b) Homo Cooperans: institutions for collective action and the compassionate society [inaugural lecture]

De Moor T (2018) De toekomst van bewonersoverlegorganisaties. Sociaal Bestek 80:52-54

Delhey J, Newton K (2005) Predicting cross-national levels of social trust: global pattern or Nordic Exceptionalism? Eur Sociol Rev 21(4):311-327

Dong Y, Peng C-YJ (2013) Principled missing data methods for researchers. SpringerPlus 2:2. https://doi.org/10.1186/2193-1801-2222

Downing TE (1974) Irrigation and moisture-sensitive periods: A Zapotec case. In: Downing TE, Gibson MG (eds) Irrigation's impact on society. University of Arizona Press, Tucson, pp 113-122

Faris JC (1972) Cat harbour: a newfoundland fishing settlement. Institute of Social and Economic Research, Memorial University of Newfoundland, St. John's, Newfoundland

Fernea RA (1970) Shaykh and Effendi: Changing patterns of authority among the El Shabana of southern Iraq. Harvard Middle Eastern Studies (Vol. 14). Harvard University Press, Cambridge, MA

Firth R (1966) Malay fishermen: Their peasant economy. Routledge and Kegan Paul Ltd., London

Flache A, Mäs M (2008) Why do faultlines matter? A computational model of how strong demographic faultlines undermine team cohesion. Simul Model Pract Theory 16(2):175-191. https://doi.org/10. 1016/j.simpat.2007.11.020

Forman S (1970) The raft fishermen: Tradition and change in the Brazilian peasant economy. Indiana University Press, Bloomington

Fraser TM Jr (1960) Rusembilan: A Malay fishing village in southern Thailand. Cornell University Press, Ithaca, NY

Fraser TM Jr (1966) Fishermen of south Thailand: The Malay villagers. Holt, Rinehart \& Winston, Inc., New York

Fukuyama F (1995) Trust: the social virtues and the creation of prosperity. The Free Press, New York

Fung JMY, Au W (2014) Effect of inequality on cooperation: heterogeneity and hegemony in public goods dilemma. Organ Behav Hum Decis Process 123(1):9-22. https://doi.org/10.1016/j.obhdp.2013. 10.010

Gächter S, Herrmann B, Thöni C (2004) Trust, voluntary cooperation, and socio-economic background: survey and experimental evidence. J Econ Behav Organ 55(4):505-531. https://doi.org/10. 1016/j.jebo.2003.11.006

Gaspart F, Platteau J-P (2007) Heterogeneity and collective action for effort regulation: lessons from the Senegalese small-scale fisheries. In: Baland J-M, Bardhan P, Bowles S (eds) Inequality, cooperation, and environmental sustainability. Russell Sage Foundation, New York

Geertz C (1967) Organization of the Balinese subak. In: Coward EW Jr (ed) Irrigation and agricultural development in Asia: Perspectives from the social sciences. Cornell University Press, Ithaca, NY, pp $70-90$ 
Gehrig S, Schlüter A, Hammerstein P (2019) Sociocultural heterogeneity in a common pool resource dilemma. PLoS One 14(1):-e0210561. https://doi.org/10.1371/journal.pone.0210561

Gelman A, Su Y-S (2018) Package "arm"

Gillespie VA (1975) Farmer irrigation associations and farmer cooperation. East-West Food Institute (No. 3). East-West Center, Honolulu, $\mathrm{HI}$

Gordon ET (1981) Phases of development and underdevelopment in a Caribbean Fishing Village: San Pedro, Belize. Ph.D. dissertation, Stanford University. [ILL: University of Wisconsin-Milwaukee]

Gray R (1963) The Sonjo of Tanganyika: An anthropological study of an irrigation-based society. Oxford University Press for the International African Institute, London

Grossinger RS (1975) The strategy and ideology of lobster fishing on the back side of Mt. Desert Island, Hancock County, Maine. Unpublished Ph.D. dissertation, University of Michigan, Ann Arbor, MI

Gustafson WE, Reidinger RB (1971) Delivery of canal water in north India and West Pakistan. Econ Political Wkly 6:A157-A162

Hackett S, Schlager E, Walker J (1994) The role of communication in resolving commons dilemmas: experimental evidence with heterogeneous appropriators. J Environ Econ Manag 27(2):99-126. https://doi.org/10.1006/jeem.1994.1029

Hafid A, Hayami Y (1979) Mobilizing local resources for irrigation development: The subsidi desa case of Indonesia. In: Taylor DC, Wickham TH (eds) Irrigation policy and the management of irrigation systems in southeast Asia. The Agricultural Development Council, Bangkok, pp 123-142

Han S-B (1972) Socioeconomic organization and change in Korean fishing villages: A comparative study of three fishing communities. Unpublished doctoral dissertation, Michigan State University, Lansing, MI

Hardin G (1968) The tragedy of the commons. Science 162(3859):12431248

International Migration report 2019. (2019). Department of Economic and Social Affairs, United Nations

Jehn KA, Northcraft GB, Neale MA (1999) Why differences make a difference: a field study of diversity, conflict, and performance in workgroups. Adm Sci Q 44(4):741-763. https://doi.org/10.2307/ 2667054

Jiang Y, Cheng J, Li S (2009) Temporal changes in the fish community resulting from a summer fishing moratorium in the northern East China Sea. Mar Ecol Prog Ser 387:265-273. https://doi.org/10. 3354/meps08078

Johnson RN, Libecap GD (1982) Contracting problems and regulation: the case of the fishery. Am Econ Rev 72(5):1005-1022

Jones EC (2004) Wealth-based trust and the development of collective action. World Dev 32(4):691-711. https://doi.org/10.1016/j. worlddev.2003.10.009

Judd CM, Kenny DA (1981) Process analysis: estimating mediation in treatment evaluations. Eval Rev 5(5):602-619. https://doi.org/10. 1177/0193841X8100500502

Keuschnigg M, Schikora J (2014) The dark side of leadership: an experiment on religious heterogeneity and cooperation in India. J SocioEcon 48:19-26. https://doi.org/10.1016/j.socec.2013.09.006

Khan AMA, Gray TS, Mill AC, Polunin NVC (2018) Impact of a fishing moratorium on a tuna pole-and-line fishery in eastern Indonesia. Mar Policy 94:143-149. https://doi.org/10.1016/j.marpol.2018.05. 014

Knack S, Keefer P (1997) Does social capital have an economic payoff? A cross-country investigation. Q J Econ 112(4):1251-1288

Komakech HC, Van der Zaag P, Van Koppen B (2012) The dynamics between water asymmetry, inequality and heterogeneity sustaining canal institutions in the Makanya catchment, Tanzania. Water Policy 14(5):800-820
Kotsonias G (1984) The Messolonghi-Etolico lagoon of Greece: Socioeconomic and ecological interactions of cooperative and independent fishermen. In: Kapetsky JM, Lasserre G (eds) Management of coastal lagoon fisheries. GFCM Studies and Reviews (Vol. 2(61)). Food and Agriculture Organization, Rome

Kottak C (1966) The structure of equality in a brazilian fishing community. Columbia University, Ph.D. dissertation

Kurekin AA, Loveday BR, Clements O, Quartly GD, Miller PI, Wiafe G, Agyekum KA (2019) Operational monitoring of illegal fishing in Ghana through exploitation of satellite earth observation and AIS data. Remote Sens 11(3):293. https://doi.org/10.3390/rs11030293

Laitos R (1986) Rapid appraisal of Nepal irrigation systems. Water Management Synthesis Project Report No. 43, Colorado State University, Fort Collins

Lando RP (1979) The gift of land: Irrigation and social structure in a Toba Batak village. Unpublished doctoral dissertation, University of California, Riverside, CA

La Porta R, Lopez-de-Silanes F, Shleifer A, Vishny RW (1997) Trust in large organizations. Am Econ Rev 87(2):333-338

Leigh A (2006a) Trust, inequality and ethnic heterogeneity. Econ Rec 82(258):268-280. https://doi.org/10.1111/j.1475-4932.2006.00339.

Leigh A (2006b) Does equality lead to fraternity? Econ Lett 93(1):121125. https://doi.org/10.1016/j.econlet.2006.04.003

Longépé N, Hajduch G, Ardianto R, De Joux R, Nhunfat B, Marzuki MI, Fablet R, Hermawan I, Germain O, Subki B, Farhan R, Muttaqin AD, Gaspar P (2018) Completing fishing monitoring with spaceborne vessel detection system (VDS) and automatic identification system (AIS) to assess illegal fishing in Indonesia. Mar Pollut Bull 131:33-39

Lowdermilk MK, Clyma W, Early AC (1975) Physical and socio-economic dynamics of a watercourse in Pakistan's Punjab: System constraints and farmers' responses. Water Management Technical Report No. 42, Colorado State University Press, Fort Collins

MacKinnon DP, Warsi G, Dwyer JH (1995) A simulation study of mediated effect measures. Multivar Behav Res 30(1):41-62. https:// doi.org/10.1207/s15327906mbr3001 3

Martin E, Yoder R (1983a) The Chherlung Thulo Kulo: A case study of a farmer-managed irrigation system. In: Agricultural Projects Services Centre and theAgricultural Development Council Inc. (Ed) Water management in Nepal: Proceedings of the seminar on water management issues. Kathmandu, Nepal: Ministry of Agriculture, [Appendix I, pp. 203-217]

Martin E, Yoder R (1983b) Water allocation and resource mobilization for irrigation: A comparison of two systems in Nepal. Paper presented at the Annual meeting of the Nepal Studies Association, Twelfth annual conference on South Asia, University of Wisconsin. Madison, November, pp 4-6

Martin E, Yoder R (1986) Institutions for irrigation management in farmer-managed systems: Examples from the hills of Nepal. Research Paper No. International Irrigation Management Institute, Digana Village, Sri Lanka, p 5

Martin KO (1973) The law in St. John's says...: Space division and resource allocation in the Newfoundland fishing community of Fermeuse. Unpublished Master's thesis. Memorial University of Newfoundland, St. John's, Newfoundland

Martin KO (1979) Play by the rules or don't play at all: Space division and resource allocation in a rural Newfoundland fishing community. In: Andersen R (ed) North Atlantic maritime cultures. Mouton, The Hague, pp 277-298

Matsumoto H, Furusho M, Fuchi M (2016) Research on the utilization of AIS for fishing boat. J Mar Res 5:25-34

Meinzen-Dick RS (1984) Local management of tank irrigation in south India: Organization and operation. Cornell Studies in Irrigation (No. 3). Cornell University, Ithaca, NY 
Merrey DJ, Wolf JM (1986) Irrigation management in Pakistan: Four papers. International Irrigation Management Research Paper No. 4, Digana Village, Sri Lanka [November]

Miller D (1982) Mexico's Caribbean fishery: Recent change and current issues. Unpublished doctoral dissertation, University of WisconsinMilwaukee

Miller D (1988) Technology. The Evolution of Mexico's Caribbean Spiny Lobster Fishery. M.S. thesis, State University of New York at Cortland, Territoriality and Ecology

Mirza AH, Merrey DJ (1979) Organizational problems and their consequences on improved watercourses in Punjab. Water Management Technical Report No. 55. Fort Collins: Water Management Research Project, Colorado State University

Mitchell WP (1976) Irrigation and Community in the Central Peruvian Highlands. Am Anthropol 78(1):25-44

Mitchell WP (1977) Irrigation farming in the Andes: Evolutionary implications. In: Halperin R, Dow J (eds) Peasant livelihoods: Studies in economic anthropology and cultural ecology. St. Martin's Press, New York, pp 36-59

Mayer M (2019) Package 'missRanger', fast imputation of missing values (1.0.4) [computer software]

Molinas JR (1998) The impact of inequality, gender, external assistance and social capital on local-level cooperation. World Dev 26(3):413 431. https://doi.org/10.1016/S0305-750X(97)10066-3

Natale F, Gibin M, Alessandrini A, Vespe M, Paulrud A (2015) Mapping fishing effort through AIS data. PLoS One 10(6):e0130746. https:// doi.org/10.1371/journal.pone.0130746

Netting RMC (1974) The system nobody knows: Village irrigation in the Swiss Alps. In: Downing T, Gibson M (eds) Irrigation's impact on society. University of Arizona Press, Tucson, pp 67-76

Netting RMC (1981) Balancing on an alp: Ecological change and continuity in a swiss mountain community. Cambridge University Press, New York

Nettle D, Dunbar RIM (1997) Social markers and the evolution of reciprocal exchange. Curr Anthropol 38(1):93-99

Nietschmann B (1972) Hunting and fishing focus among the Miskito Indians, eastern Nicaragua. Hum Ecol 1(1):41-67

Nietschmann B (1973) Between land and water: The subsistence ecology of the Miskito Indians, eastern Nicaragua. Seminar Press, New York

Nirola RR, Pandey RP (1987) A comparative case study of two community managed irrigation systems in Chitwan District. Paper presented at the National seminar on irrigation management in Nepal. June, Chitwan, pp 4-5

Olson M (1965) The logic of collective action: pubic goods and the theory of groups. Harvard University Press, Cambridge

Ongkingco PS (1973) Case studies of Laoag-Vintar and NazarenoGamutan irrigation systems. Philipp Agric 59(9-10):374-380

Ostrom E (1990) Governing the commons: the evolution of institutions for collective action. Cambridge University Press

Ostrom E, Agrawal A, Blomquist W, Schlager E, Tang SY (1989) CPR coding manual. Indiana University, Bloomington

Ostrom E, Walker J, Gardner R (1992) Rules, games and common-pool resources. Am Polit Sci Rev 86(2):404-417. https://doi.org/10. $2307 / 1964229$

Palmer CT, Sinclair PR (2008) Perceptions of a fishery in crisis: dragger skippers on the Gulf of ST. Lawrence cod moratorium. Soc Nat Resour 9(3):267-279

Pan Q, Wei R (2016) Fraction of missing information $(\gamma)$ at different missing data fractions in the 2012 NAMCS physician workflow mail survey. Appl Math 7(10):1057-1067. https://doi.org/10.4236/ am.2016.710093

Pasta DJ (2009) Learning when to be discrete: continuous vs. categorical predictors 10. http://support.sas.com/resources/papers/ proceedings09/248-2009.pdf
Poteete AR, Ostrom E (2004) Heterogeneity, group size and collective action: the role of institutions in forest management. Dev Chang 35(3):435-461

Potter JM (1976) Thai peasant social structure. The University of Chicago Press, Chicago

Powers AM (1984) Social organization in a Newfoundland fishing settlement on the Burin Peninsula. Unpublished Ph.D. dissertation, State University of New York at Stony Brook, NY

Pradhan P (1988) Pattern of irrigation organizations in Nepal: Comparative study of 21 farmer-managed systems. Manuscript, International Irrigation Management Institute, Kathmandu, Nepal

Putnam RD (2000) Bowling alone: the collapse and revival of American community. Simon \& Schuster, New York

Putnam RD (2007) E pluribus Unum: diversity and community in the twenty-first century the 2006 Johan Skytte prize lecture. Scand Polit Stud 30(2):137-174. https://doi.org/10.1111/j.1467-9477.2007. 00176.x

Raychaudhuri B (1968) Fishing rituals of the marine fisherfolk. Bulletin of the anthropological survey of India 17(2):83-116

Raychaudhuri B (1980) The moon and net: Study of a transient community of fishermen at Jambudwip. Anthropological Survey of India, Calcutta

Reidinger RB (1974) Institutional rationing of canal water in Northern India: conflict between traditional patterns and modern needs. Econ Dev Cult Change 23(1):79-104

Reidinger RB (1980) Water management by administrative procedures in an Indian irrigation system. In: Coward EW Jr (ed) Irrigation and agricultural development in Asia: Perspectives from the social sciences. Cornell University Press, Ithaca, NY, pp 263-288

Regmi, A. R. (2007). The role of group heterogeneity in collective action: a look at the intertie between irrigation and forests. Case studies from Chitwan, Nepal [Ph.D., Indiana University]. https://search. proquest.com/docview/304853767/abstract/ 27109DC8519A40B4PQ/1

Romano A, Balliet D, Yamagishi T, Liu J, H. (2017) Parochial trust and cooperation across 17 societies. Proc Natl Acad Sci U S A https:// ezproxy-prd.bodleian.ox.ac.uk:8159/pmc/articles/PMC5715771/ 114:12702-12707

Rubin DB (1987) Multiple imputation for nonresponse in surveys. John Wiley \& Sons, Inc., New York

Ruttan LM (2006) Sociocultural heterogeneity and the commons. Curr Anthropol 47(5):843-853. https://doi.org/10.1086/507185

Ruttan LM (2008) Economic heterogeneity and the commons: effects on collective action and collective goods provisioning. World Dev 36(5):969-985. https://doi.org/10.1016/j.worlddev.2007.05.005

Sanchirico JN, Holland D, Quigley K, Fina M (2006) Catch-quota balancing in multispecies individual fishing quotas. Mar Policy 30: $767-785$

Schlager E (1990) Model specification and policy analysis: the governance of coastal fisheries. Indiana University Bloomington, IN

Shanmugaratnam N (1996) Nationalisation, privatisation and the dilemmas of common property management in Western Rajasthan. $\mathrm{J}$ Dev Stud 33(2):163-187. https://doi.org/10.1080/ 00220389608422461

Sharma, L. N., Gyeltshen T, Lhapchu, Chhogyel S, Dorji R, Dorji S, Duckpa U, Bajracharya J, Dorji T (1989) Report on Thulo Kulo (Upper) Irrigation System (FMIS). In: Report on training cum observation on rapid appraisal methods and water users: Association Activities, edited by the IIMI, Annex 10. Digana Village via Kandy, Sri Lanka: IIMI

Singleton S (2001) How distributional conflicts shape co-management institutions and collaborative environmental policy in the United States. In: "Economic inequality, collective action and environmental sustainability" workshop. Institute, Santa Fe 
Shortall D (1973) Environmental perception in two local fisheries: A case study from Eastern Newfoundland. Unpublished Ph.D. dissertation, Memorial University of Newfoundland, St. John's Newfoundland

Sobel ME (1982) Asymptotic confidence intervals for indirect effects in structural equation models. Sociol Methodol 13:290-312. https:// doi.org/10.2307/270723

Spooner B (1971) Continuity and change in rural Iran: The eastern Deserts. In: Chelkowski PJ (ed) Iran: Continuity and variety. The Center for Near Eastern Studies and the Center for International Studies, New York University, New York, pp 1-19

Spooner B (1972) The Iranian deserts. In: Spooner B (ed) Population growth: Anthropological implications. MIT Press, Cambridge, MA, pp 245-268

Spooner B (1974) Irrigation and society: The Iranian plateau. In: Downing T, Gibson M (eds) Irrigation's impact on society. University of Arizona Press, Tucson, pp 43-57

Stekhoven DJ, Bühlmann P (2012) MissForest — non-parametric missing value imputation for mixed-type data. Bioinformatics 28(1):112118. https://doi.org/10.1093/bioinformatics/btr597

Sturgess NH, Dow N, Belin P (1982) Management of the Victorian scallop fisheries: retrospect and prospect. In: Sturgess NH, Meany TF (eds) Policy and practice in fisheries management. Australian Government Publishing Service, Canberra, pp 277-316

Sutherland A (1986) Caye Caulker: economic success in a Belizean Fishing Village. Westview Press, Boulder, CO

Tang SY (1989) Institutions and collective action in irrigation systems [Ph.D., Indiana University]. https://search.proquest.com/docview/ 303782987/abstract/2916AAA57E504088PQ/1

Tan-Kim-Yong U (1983) Resource mobilization in traditional irrigation systems of Northern Thailand: A comparison between the lowland and upland irrigation communities. Unpublished Ph.D. dissertation, Cornell University, Ithaca, NY

Tingley D, Yamamoto T, Hirose K, Keele L, Imai K (2014) Mediation: $R$ package for causal mediation analysis. J Stat Softw 59(5). https:// doi.org/10.18637/jss.v059.i05

Uslaner EM (2002) The moral foundations of trust. Cambridge University Press http://gvptsites.umd.edu/uslaner/ uslanermoralfoundations.pdf

Van Buuren S (2019) Package 'mice', multivariate imputation by chained equations (3.5.0) [computer software]

Vander Velde EJ (1971) The distribution of irrigation benefits: A study in Haryana, India. Unpublished Ph.D. dissertation. The University of Michigan, Ann Arbor, MI

Vander Velde EJ (1980) Local consequences of a large-scale irrigation system in India. In: Coward EW Jr (ed) Irrigation and agricultural development in Asia: Perspectives from the social sciences. Cornell University Press, Ithaca, NY, pp 299-328

Varughese G, Ostrom E (2001) The contested role of heterogeneity in collective action: some evidence from community forestry in Nepal. World Dev 29(5):747-765

Vermillion D (1999) Property rights and collective action in the devolution of irrigation system management. Workshop on Devolution of Natural Resource Management

Wade R (1985) Common property resource management in south indian villages. In: Proceedings of the conference on common property resource management, 231-258. Prepared by the Panel on Common Property Resource Management, Board on Science and Technology for International Development, National Research Council. National Academy Press, Washington, DC

Wade R (1988) Village republics: Economic conditions for collective action in south India. Cambridge University Press, Cambridge, England

Wagner J (2010) The fraction of missing information as a tool for monitoring the quality of survey data. Public Opin Q 74(2):223-243. https://doi.org/10.1093/poq/nfq007

Water and Energy Commission Secretariat (1987) Naya Dhara Ko Kulo. In: Rapid appraisal study of eight selected micro-areas of farmers' irrigation systems. Final Report. Kathmandu, Nepal, Ministry of Water Resources, pp 49-62

Wiessner PW (1977) Hxaro: a regional system of reciprocity for reducing risk among the !Kung san. (volumes I and ii) [Ph.D., University of Michigan]. https://search.proquest.com/docview/302847958/ citation/BB2C14416FF1415BPQ/1

Williams R (2018) Ordinal independent variables. University of Notre Dame https://www3.nd.edu/ rwilliam/stats3/OrdinalIndependent. pdf

Wright MN, Wager S, \& Probst P (2019) Package 'ranger', a fast implementation of random forests (0.11.2) [Computer software]

Wu L, Xu Y, Wang Q, Wang F (2016) Mapping global shipping density from AIS data | the journal of navigation | Cambridge Core. Cambridge University Press 70:67-81. https://doi.org/10.1017/ S0373463316000345

Zak PJ, Knack S (2001) Trust and growth. Econ J 111(470):295-321

Publisher's note Springer Nature remains neutral with regard to jurisdictional claims in published maps and institutional affiliations. 